\title{
Lithogeochemistry, petrology, and the acid-generating potential of the Goldenville and Halifax groups and associated granitoid rocks in metropolitan Halifax Regional Municipality, Nova Scotia, Canada
}

\author{
Chris E. White ${ }^{1 *}$ and Terry A. Goodwin \\ Nova Scotia Department of Natural Resources, P.O. Box 698, Halifax, Nova Scotia B3J 2T9, Canada \\ *Corresponding author<whitece@gov.ns.ca>
}

Date received: 11 June 2011 g Date accepted: 01 September 2011

\begin{abstract}
Detailed geological mapping of the Goldenville and Halifax groups in metropolitan Halifax Regional Municipality, Nova Scotia, resulted in two-fold subdivision of both groups. The Goldenville Group was divided into the metasandstone (feldspathic wacke)-dominated Taylors Head formation and the overlying, metasiltstone-dominated, Mn-rich Beaverbank formation. The Halifax Group was divided into the Cunard formation, dominated by sulphide-rich slate, and the overlying Bluestone formation, consisting of mainly metasiltstone and metasandstone. Lithogeochemical and petrological studies resulted in the characterization of the Beaverbank, Cunard, and Bluestone formations as potential acid-producing units with pyrrhotite as the main iron-sulphide mineral. The presence of acid rock drainage (ARD) is governed by bulk-rock chemical composition and mineral assemblage. To test the predictability of ARD production, a portable XRF instrument was used to obtain relatively inexpensive whole-rock and sulphur data that were used in conjunction with conventional XRF analyses and acid-base accounting tests. Results from the three methods compare favourably. Use of the portable XRF instrument facilitates a timely and cost-effective approach to predicting ARD but does not replace the legally mandated acid-base accounting procedure.
\end{abstract}

\section{RÉSUMÉ}

Une cartographie géologique détaillée des groupes de Goldenville et de Halifax dans la municipalité régionale de Halifax, en Nouvelle-Écosse, a donné lieu à deux divisions de ces deux groupes. Pour ce qui est du groupe de Goldenville, les deux formations suivantes ont été établies: la Formation de Taylors Head, composée principalement de métagrès (wacke feldspathique) et la Formation de Beaverbank sus-jacente, composée principalement de métasiltite riche en Mn. En ce qui concerne le groupe de Halifax, les deux formations que voici ont été identifiées: la Formation de Cunard, composée principalement d'ardoise riche en sulfures, et la Formation de Bluestone sus-jacente, composée surtout de métasiltite et de métagrès. Les études lithogéochimiques et pétrologiques ont permis d'établir que les Formations de Beaverbank, de Cunard et de Bluestone étaient susceptibles d'agir comme précurseurs acides, la pyrrhotite étant le principal minéral à sulfure de fer présent. La présence d'un drainage rocheux acide(DRA) est régie par la composition chimique de la roche brute et l'association minérale. Pour vérifier la possibilité d'un DRA, de concert avec des analyses traditionnelles à fluorescence $\mathrm{X}$ et de bilan acide-base, un appareil portatif à fluorescence $\mathrm{X}$ a été utilisé pour recueillir de manière relativement économique des données sur la roche brute et les sulfures. Les résultats obtenus par les trois méthodes se comparent bien. L'utilisation d'un appareil à fluorescence X portatif permet de prédire de manière économique et rapidement la possibilité du DRA, mais cette technique ne saurait se substituer à l'analyse du bilan acide-base prévue par la réglementation.

[Traduit par la redaction]

\section{INTRODUCTION}

A detailed bedrock mapping and sampling program combined with petrographic and stratigraphic analysis was undertaken in the metropolitan portion of the Halifax Regional
Municipality (HRM) as part of the much larger southern Nova Scotia Meguma terrane mapping program (Fig. 1) (White et al.2008; White 2010a). The purpose of the mapping program is to better characterize the stratigraphy, economic potential, and tectonic evolution of the Cambrian to Ordovician Golden- 


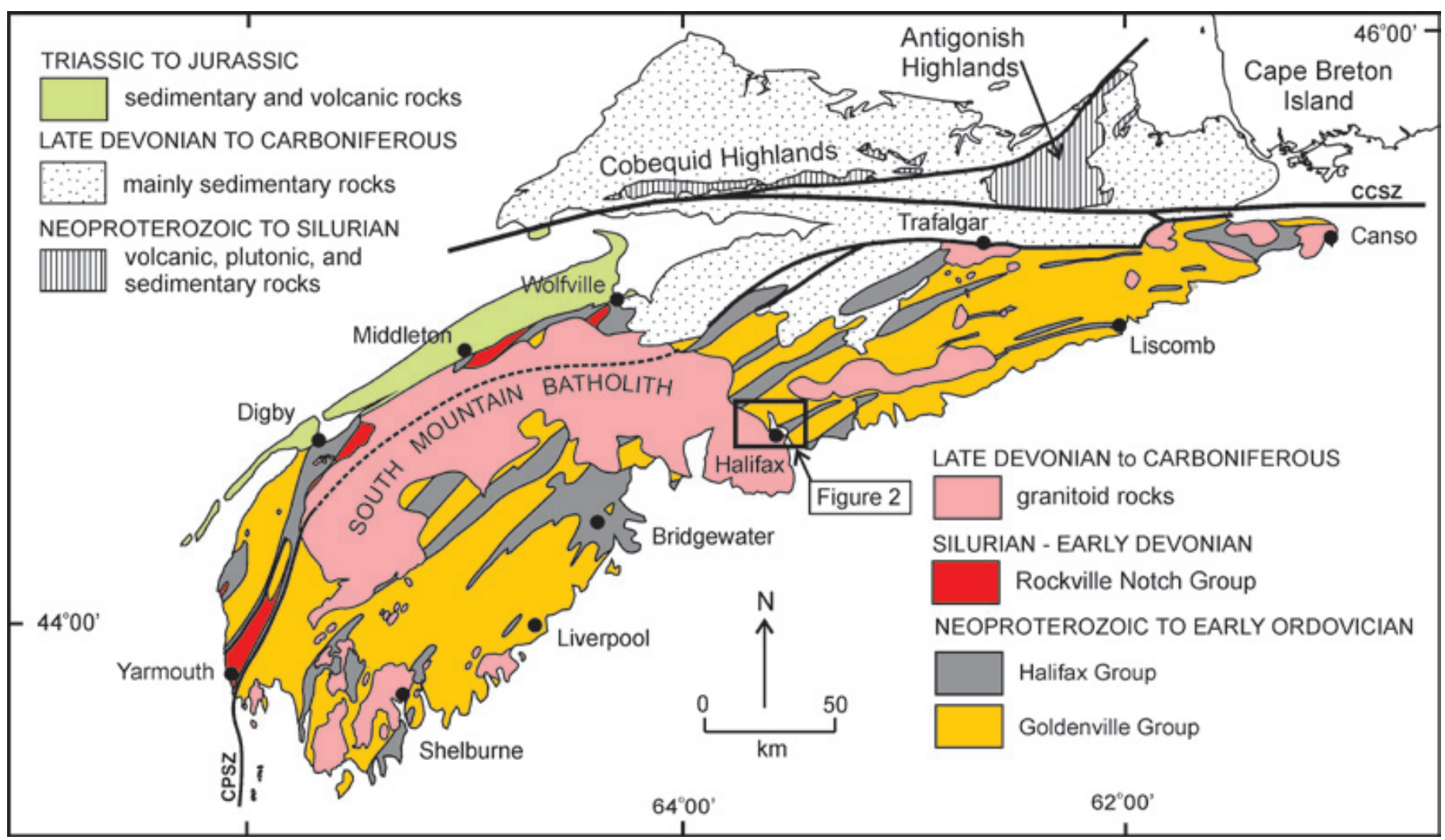

Fig. 1. Simplified geological map of the Meguma terrane of southern Nova Scotia, showing the distribution of the Goldenville and Halifax groups and other major units. The area of study is shown in the box. Abbreviations: CCSZ = Cobequid-Chedabucto shear zone; $\mathrm{CPSZ}=$ Chebogue Point shear zone.

ville and Halifax groups in southern Nova Scotia (e.g., White 2010a; White and Barr 2010). However, an important outcome from the mapping is the identification of units within HRM and elsewhere in the Goldenville and Halifax groups that have potential acid-generating hazards (e.g., Lewis et al. 1998). The production of acid and hence acid rock drainage (ARD) results from the oxidation of naturally occurring sulphide minerals in the rocks, and is a major issue facing development in the metropolitan portion of HRM. The environmental impacts associated with exposed or disturbed sulphide-rich rocks during routine construction activity (i.e., not related to metal or coal mining) are not unique to HRM and have been documented in many parts of the world (e.g., Piispanen and Nykyri, 1997; Morin et al. 2003; Peng et al. 2005; Schoeffer and Clawson 1996; Kwong et al. 2009).

Acid rock drainage is not only detrimental for fish and other aquatic species but also causes excessive premature corrosion of concrete and metal infrastructure. For these reasons many construction companies, geotechnical consulting groups, and public work agencies need to know areas in the city where ARD may be an issue in infrastructure construction projects. With the identification of sulphide-rich geological formations in HRM, the potential for ARD can be better understood, and as a result, the onset of acid drainage can be more effectively avoided.
To predict the acid generating potential from any geologic formation requires the characterization of the presence and quantity of both acid-forming minerals and neutralizing minerals in the geologic materials to be unearthed during construction operations. Although a variety of laboratory-based acid-base accounting $(\mathrm{ABA})$ tests are available to determine the potential for generating ARD content, here we employ the static British Columbia Research Initial Test (BC-RIT) method as recommended by the Nova Scotia Environment Act (1995). With the results from this test, combined with a detailed geological map, whole rock lithogeochemistry, and petrography, we can now accurately assess the acid-forming capability of formations which can be used for environmental management and subsequent mitigation of ARD in HRM. The purpose of this paper is to quantify the ARD-generating potential of rocks in the metropolitan portion of HRM.

\section{ACID ROCK DRAINAGE}

Acid rock drainage, also referred to as acid mine drainage (AMD), is a naturally occurring phenomenon that results when sulphide minerals in a rock are oxidized as a result of exposure to oxygen and water. In the absence of neutralizing material (e.g., limestone or dolomite) this oxidation causes the chemical 
breakdown of the sulphide minerals which releases sulphuric acid, iron and other metals, and sulphate into the receiving environment, typically a stream, river, or lake.

In HRM, pyrrhotite and pyrite are the primary concerns with regard to ARD, with the oxidation rate of pyrrhotite being much faster than pyrite (Fox et al. 1997). The oxidation of pyrrhotite and pyrite is complex and involves a series of multiple reactions but simplified equations can be written as follows:

(1) $\mathrm{Fe}_{1-x} \mathrm{~S}$ (pyrrhotite) $+(2-x / 2) \mathrm{O}_{2}+x \mathrm{H}_{2} \mathrm{O} \rightarrow \mathrm{SO}_{4}{ }^{2-}+(1-x)$ $\mathrm{Fe}^{2+}+2 x \mathrm{H}^{+}$

(2) $\mathrm{FeS}_{2}$ (pyrite) $+3.75 \mathrm{O}_{2}+3.5 \mathrm{H}_{2} \mathrm{O} \rightarrow 2 \mathrm{SO}_{4}{ }^{2-}+\mathrm{Fe}(\mathrm{OH})_{3}+4 \mathrm{H}^{+}$

Other minerals such as arsenopyrite, chalcopyrite, sphalerite, galena, and magnetite are commonly overlooked as potential candidates for ARD but they can also provide additional input to acid generation through the oxidation of $\mathrm{Fe}^{2+}$ and hydrolysis of $\mathrm{Fe}^{3+}$ (Moncur et al. 2009). In addition, crystal structure plays an important role in the generation of ARD. For example, the monoclinic (vs. hexagonal) form of pyrrhotite has been shown to readily weather and initiate acid production (Robinson 1996).

Waterways affected by ARD can be characterized by their acidity, high sulphate and metal content in their waters, and the metallic content of their sediments (e.g., Grande et al. 2005). Often the aesthetic quality of a waterway is reduced by the presence of a red iron hydroxide precipitate that commonly lines the bottom sediment of the receiving waters. Depending on the $\mathrm{pH}$ of the water, the rate of oxidation is greatly accelerated by a variety of bacteria (e.g., Thiobacillus thiooxidans and Ferrobacillus ferrooxidans - $\mathrm{pH}$ between 4.5 and 3.5; Thiobacillus ferrooxidans - $\mathrm{pH}$ below 3.5) (U.S. Environmental Protection Agency 1994; Eba Engineering Consultants Ltd. 2004; Blowes et al. 2005). In addition to loss of aquatic life, as well as the loss of potable and industrial water resources, ARD has been responsible for damage to engineered infrastructure such as concrete structures, buried transmission lines, culverts, bridges, and metal pipes (Earle and Callagnah 1998). Acid rock drainage, once it appears, is virtually impossible to reverse and with the current technology, its treatment can cost millions of dollars and go on for centuries (Feasby and Tremblay 1995; Jennings et al. 2008).

In addition to the acid contribution to surface waters, ARD may cause trace metals such as aluminum, arsenic, cadmium, copper, manganese, and zinc and to leach from rocks and these metals can contribute to the environmental damage, and in some cases is of greater concern than the acidity.

\section{History of ARD in the Halifax Group}

Acid rock drainage issues in Nova Scotia, in particular in the Halifax Group, were broadly researched in the late 1980s and 1990s (e.g., Pasava et al. 1995; Feetham et al. 1997; Fox et al. 1997; Zentilli and Fox 1997, and references within) but have seen limited research since that time. One of the earliest and most extensively studied sites associated with ARD in HRM involved the construction and subsequent expansion(s) of the Robert Stanfield International Airport (previously referred to as the Halifax International Airport). Here a direct correlation was demonstrated between construction activity in the Halifax Group and significant fish kills in the nearby Shubenacadie River between 1960 and 1976 (Pasava et al. 1995; Worgan 1987). Remediation and treatment costs have averaged one million dollars annually at the airport, and treatment of surface waters continues (Hicks 2003).

Construction on Highway 107 east of Dartmouth near West Petpeswick Lake during the late 1980s exposed a continuous section of Halifax Group slate which resulted in the production of ARD and the degradation of water quality and aquatic habitat. Subsequently, the acid-producing outcrop was capped with shotcrete and a small treatment facility was constructed (Fox et al. 1997). Other historic ARD issues that have arisen in HRM and elsewhere in Nova Scotia also were outlined in Fox et al. (1997).

These incidents led the Nova Scotia Department of Environment to instate the "Sulphide Bearing Material Disposal Regulations" which require testing for ARD prior to ground disturbance (Nova Scotia Environment Act 1995). However, within HRM evidence suggests that current development in Fairview, Hammonds Plains, and Middle Sackville continues to have ARD problems. The local residents in these areas who are on well-water have water softeners and filters to combat the resulting rusty stain on fixtures, discoloured laundry, and sulphur odour (Goodwin 2004). In addition, past and on-going infrastructure development such as the interchange of highways 102 and 103 as well as road building and the development of retail commercial sites in the Bayers Lake Industrial Park continue to be sources of natural ARD and acidification of local lakes (Kerekes et al., 1984; Rajaratnam 2009). More recently, construction was halted during the building of the new Dartmouth bus terminal and Bayers Lake underpass as pyritic slate was encountered on these sites, dramatically increasing project costs (Talpin 2011a, b; Stephenson 2011).

\section{GEOLOGICAL SETTING}

The first step when evaluating the acid generating potential of bedrock is to understand the geological history of the area and describe the geology and mineralogy of rock formations in detail (Coastech Research Inc 1991; U.S. Environmental Protection Agency 1994; Price 2005, 2009; Jennings et al. 2008).

The earliest geological study in the Halifax area was undertaken by Faribault $(1907,1908)$ who divided the area into an older "Quartzite Division" and younger "Slate Division" intruded by coarse-grained granite. Faribault (1907) recognized the rusty character of the "Slate Division" and described the unit as highly ferruginous and altered with metamorphic minerals close to the granite contact. The area was next mapped by MacDonald and Horne (1987) but they focused primarily on the igneous units and compiled data from the earlier work 
of Faribault (1908) for the metasedimentary units. Following current practice, they assigned the "Quartzite" and "Slate" divisions to the Cambrian-Ordovician Goldenville and Halifax formations, respectively.

Recent 1:10 000-scale mapping in HRM (White et al. 2008) was undertaken to update the old geological map of Faribault (1908). As a result, new formations were recognized and the Goldenville and Halifax formations were elevated to 'group' status. The older unit, the Goldenville Group, occurs in the northern and eastern parts of HRM (Fig. 2). It is divided into two formations: Taylors Head and Beaverbank (White et al. 2008; White 2010a, b). The Taylors Head formation consists of grey, thickly bedded and weakly cleaved, metasandstone interbedded with minor green to grey, cleaved metasiltstone, and rare black to rusty slate. Calc-silicate nodules and pyrite cubes are locally common. The contact with the overlying Beaverbank formation is conformable and marked by a decrease in thickly bedded metasandstone over tens of meters. The Beaverbank formation consists of grey to black, cleaved metasiltstone interbedded with minor thin, light grey metasandstone and black graphitic slate. Thin brown to black manganeserich limestone beds and nodules are common. Close to the contact with granite of the South Mountain Batholith these manganese-rich limestone beds and nodules become garnet (spessartine)-rich coticules.

The overlying Halifax Group isdivided into the Cunard and Bluestone formations (White et al. 2008). In the Halifax area, the Cunard formation conformably overlies the Beaverbank formation of the Goldenville Group and is characterized by black, commonly rusty on weathered surfaces, graphitic slate and metasiltstone interbedded with 10 to $30 \mathrm{~cm}$ thick, cross-laminated fine-grained metasandstone. This formation typically contains abundant pyrrhotite and pyrite, with lesser amounts of chalcopyrite, galena, sphalerite, and arsenopyrite (e.g., Fox et al. 1997; Haysom et al. 1997; Betts-Robertson 1998; Clarke et al. 2009).

The conformably overlying Bluestone formation consists of grey thinly bedded metasiltstone and slate, minor metasandstone and calcareous nodules (Jamieson et al. 2005a, b, 2011; White et al. 2008) and has recently been subdivided into several informal members (Jamieson et al. 2011). In contrast to metasandstone in the underlying Cunard formation, the metasandstone lacks prominent cross-laminations. The Bluestone formation generally lacks obvious sulphide minerals.

The Goldenville and Halifax groups were regionally metamorphosed (greenschist facies) and deformed into northeaststriking, upright, tight to open folds (Fig. 1,2) with a well developed axial planar cleavage during the ca. 406-388 Ma Neoacadian Orogeny (van Staal 2007; Moran et al. 2007; White et al. 2008; White 2010a).

The ca. 380-373 Ma peraluminous South Mountain Batholith (SMB) intruded the Goldenville and Halifax groups and produced a narrow (up to $2 \mathrm{~km}$ wide), well developed contact metamorphic aureole that is superimposed on regional greenschist facies mineral assemblages and textures (Jamieson et al. 2005a, b, 2011; White et al. 2008) (Fig. 2). A major northwest- striking shear zone is present in the contact aureole adjacent to the northeastern margin of the South Mountain Batholith (Fig. 2) and was active during intrusion (Culshaw and Bhatnagar 2001; White et al. 2008).

Within the northeastern margin of the SMB, a narrow ( 0.5 to $1 \mathrm{~km}$ wide) northwest-trending zone of grey, medium grained, equigranular granodiorite with minor alkali feldspar megacrysts is recognized and herein termed the Quarry Lake granodiorite. Locally at the contact with the country rocks this unit contains abundant metasaedimentary xenoliths. Farther southwest into the batholith several plutonic units are defined (Sandy Lake and Harrietsfield monzogranites, and Halifax Peninsula leucomonzogranite) which range from fine- to coarsegrained to megacrystic monzogranite to leucomonzogranite (MacDonald and Horne 1987; MacDonald 2001). All these units are intruded by the late-stage medium-grained two-mica Tantallon leucomonzogranite (Fig. 2).

\section{METHODOLOGY}

Field mapping (1:10 000-scale) was performed during the summers from 2007 to 2010 and included a comprehensive and detailed sampling program. A total of 239 samples from the stratified units and 21 samples from granitoid outcrops in the South Mountain Batholith were collected for petrographic analysis. A total of 76 psammitic and 32 pelitic lithologies were thin-sectioned in order to obtain detailed information on mineralogy and grade of metamorphism. An additional 21 thin sections from the South Mountain Batholith were studied to document the mineralogy in the granitoid units. Twenty-eight samples were selected for polished thin sections and whole-rock geochemistry representing each lithology in the Goldenville and Halifax groups.

Magnetic susceptibility data were collected on each sample using a handheld KT-9 Kappameter. The KT-9 uses a $10 \mathrm{kHz}$ LC oscillator and an inductive coil and automatically displays the true measured susceptibility of the sample in dimensionless, System International (SI) units. The maximum sensitivity of the KT-9 is $1 \times 10^{-5}$ SI units. In this study, all measurements were recorded to $1 \times 10^{-3} \mathrm{SI}$ units.

To determine the background ARD potential, samples were chosen on the basis that they represented the typical lithology at any one outcrop and did not contain abundant visible sulphide mineralization or weathering features. This approach is in contrast to previous ARD studies in HRM (i.e., Fox et al. 1997) that specifically targeted sulphide-bearing lithologies. Samples were pre-crushed to $<180$ microns using a tungstencarbide mill and major, trace, rare earth element, and total sulphur and carbon analysis were done by ICP-MS at Acme Analytical Laboratories (Vancouver) Ltd . Major oxides and several minor elements were analysed by ICP-emission spectrometry following a lithium metaborate/tetraborate fusion and dilute nitric digestion. Trace elements were determined by ICP mass spectrometry following a lithium metaborate/ tetraborate fusion and nitric acid digestion. Loss on ignition 


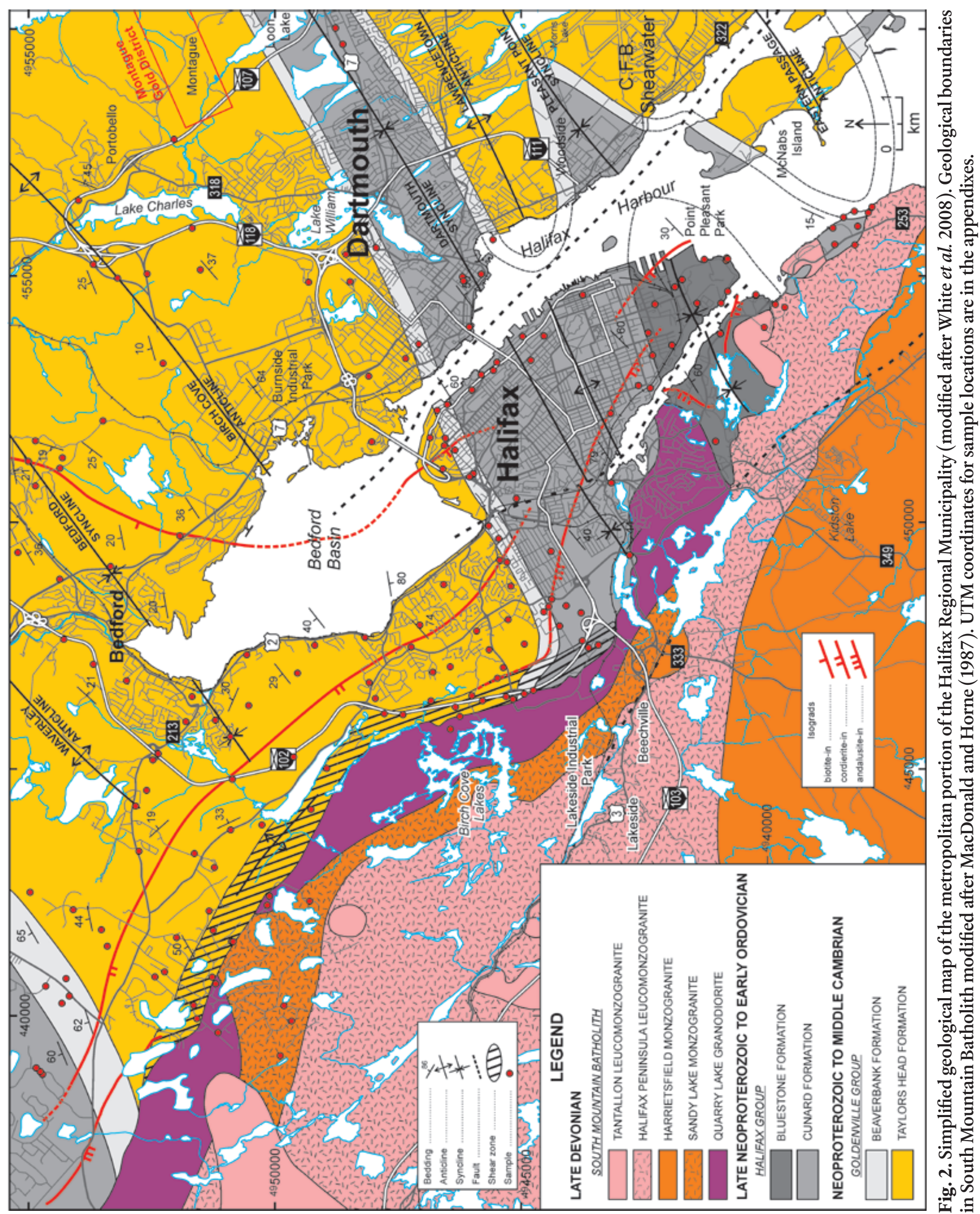



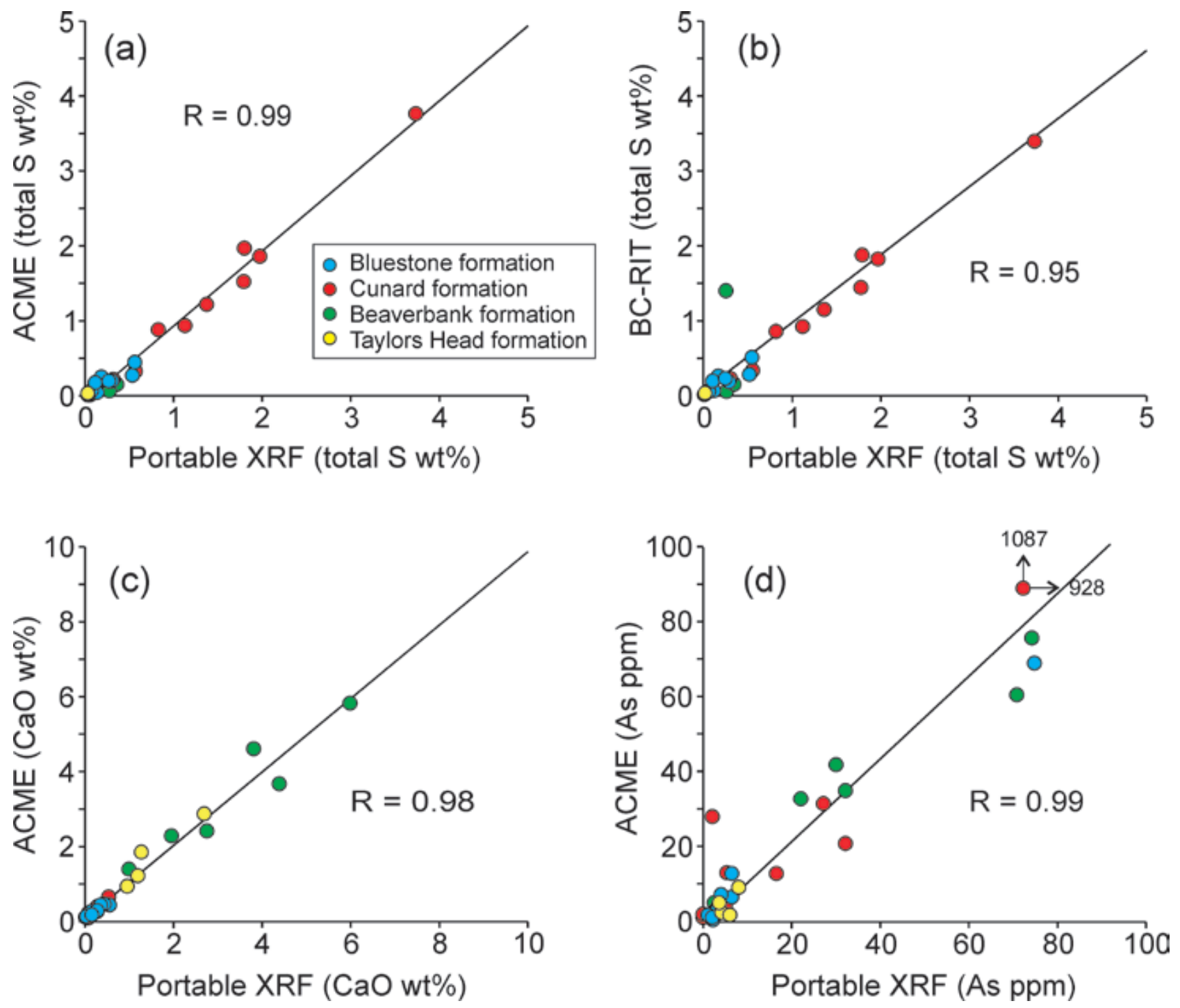

Fig. 3. Selected whole rock results using the portable XRF compared with the ACME and BC-RIT results on the sample samples. (a) Plot of total S (wt.\%); portable XRF against ACME. (b) Plot of total S (wt.\%); portable XRF against BC-RIT. (c) Plot of $\mathrm{CaO}$ (wt.\%); portable XRF against ACME. (d) Plot of As (ppm); portable XRF against ACME.

(LOI) is by weight difference after ignition at $1000^{\circ} \mathrm{C}$. Four samples from the Taylors Head formation, 6 from the Beaverbank formation, 10 from the Cunard formation, and 8 from the Bluestone formation were analyzed (Table $1 \mathrm{a}, \mathrm{b})$.

In Nova Scotia, the Sulphide Bearing Material Disposal Regulations (Section 66 of the Nova Scotia Environment Act 1995) require that all samples submitted for ARD analysis should use the static British Columbia Research Initial Test (BC-RIT) and rocks having a sulphide sulphur content equal to or greater than $0.4 \%\left(12.51 \mathrm{~kg} \mathrm{H}_{2} \mathrm{SO}_{4} /\right.$ tonne $)$ must be considered as hazardous ARD material. A total of 23 bedrock samples were submitted to the Minerals Engineering Centre (MEC) at Dalhousie University, Halifax, Nova Scotia, for processing and analysis using the BC-RIT method (Table 2). Each sample was analyzed by MEC for total sulphur (LECO furnace), sulphide sulphur (after determining sulphate sulphur by hydrochloric acid diges- tion, precipitation of the sulphate using barium chloride and gravimetric finish to yield the sulphate sulphur) and for its acid producing/consumption ability using the BC-RIT method (Duncan and Bruynesteyn 1979).

In addition, all 260 samples were analyzed using a portable X-5000 XRF instrument (hereafter termed portable XRF) manufactured by Innov-X which was acquired recently by the Nova Scotia Department of Natural Resources. It uses a 10W tantalum anode light-element X-ray tube with a resolution of $<165 \mathrm{eV}$. The beam is approximate $8 \mathrm{~mm}$ in diameter and measures $25+$ transitions metals including selected rare earth elements. Samples were analyzed using the Soil 3 Beam mode with 60 second counts on each beam; however, this mode does not measure elements lighter than $\mathrm{Na}$ (e.g., $\mathrm{Si}, \mathrm{Al}$, and $\mathrm{Mg}$ ).

Traverses across rock slabs, greater than $1 \mathrm{~cm}$ thick, were averaged (3-5 spots on fine-grained samples and 5-10 spots 
on coarsergrained samples). The samples represent psammitic, pelitic, and calc-silicate rocks in all the formations in the Goldenville and Halifax groups, arranged in stratigraphic order, and include 139 from the Taylors Head formation; 34 from the Beaverbank formation, 39 from the Cunard formation, and 27 from the Bluestone formation. In addition, 21 samples from the South Mountain Batholith were analyzed. Rock type, UTM coordinates, and major and trace data are summarized in Appendices A-E.

\section{Quality assurance and quality control}

the portable X-5000 XRF provides rapid and simultaneous analyses of several elements with minimal sample preparation. To assess the reliability of analyses using the portable $\mathrm{XRF}$ the results are compared with the ACME results on the same samples. In addition, two internal reference samples (metasandstone and slate from the Goldenville and Halifax groups, respectively) were routinely analyzed to evaluate the portable XRF's performance. This check aids in estimation of the precision and accuracy and hence ensures meaningful interpretation of the data. Scatter plots for selected elements (S, $\mathrm{Ca}$, and $\mathrm{As}$ ) from $\mathrm{ACME}$ and the portable XRF results were constructed and compared to the total $S$ analyzed by BC-RIT (Fig. 3). Correlation coefficients ( $\mathrm{r}$-values) on each pair were also calculated. The results show excellent reproducibility $(\mathrm{r} \geq$ 0.95). Comparing the results from ACME to the portable XRF data yielded correlation coefficients that range from 0.88 to 0.98 for $\mathrm{K}_{2} \mathrm{O}, \mathrm{TiO}_{2}, \mathrm{MnO}, \mathrm{Fe}_{2} \mathrm{O}_{3}{ }^{\mathrm{T}}, \mathrm{Ba}, \mathrm{Cu}, \mathrm{Nb}, \mathrm{Pb}, \mathrm{Rb}, \mathrm{Sr}, \mathrm{V}, \mathrm{Y}$, $\mathrm{Zn}$, and $\mathrm{Zr}$ pairs (not shown). There is no significant discrepancy in the data between the ACME and portable XRF and hence the portable XRF results can be used with a significant degree of confidence.

\section{PETROGRAPHY}

\section{Goldenville and Halifax groups}

In rocks of the Goldenville and Halifax groups away from the contact metamorphic effects of the South Mountain Batholith in the HRM area, regional greenschist facies (chlorite zone) metamorphic minerals and textures are preserved. Here the original clay-sized material in the slate as well as the matrix in metasandstone and metasiltstone has been recrystallized to a mixture of very fine-grained sericite, epidote, and chlorite. Quartz is the most abundant detrital component in the metasandstone, with lesser amounts of feldspar and minor or no lithic fragments (Fig. 4). Most feldspar grains are subrounded and consist of albitic plagioclase. It is rarely twinned and partially altered to sericite, epidote, or calcite. Potassium feldspar is rare. The metasandstone has between 18 and $38 \%$ matrix and is classified (using the system of Boggs, 2001, shown in Fig. 4a) as feldspathic wacke (Fig. 4b). Detrital muscovite is present in many samples and ranges in abundance up to $5 \%$.
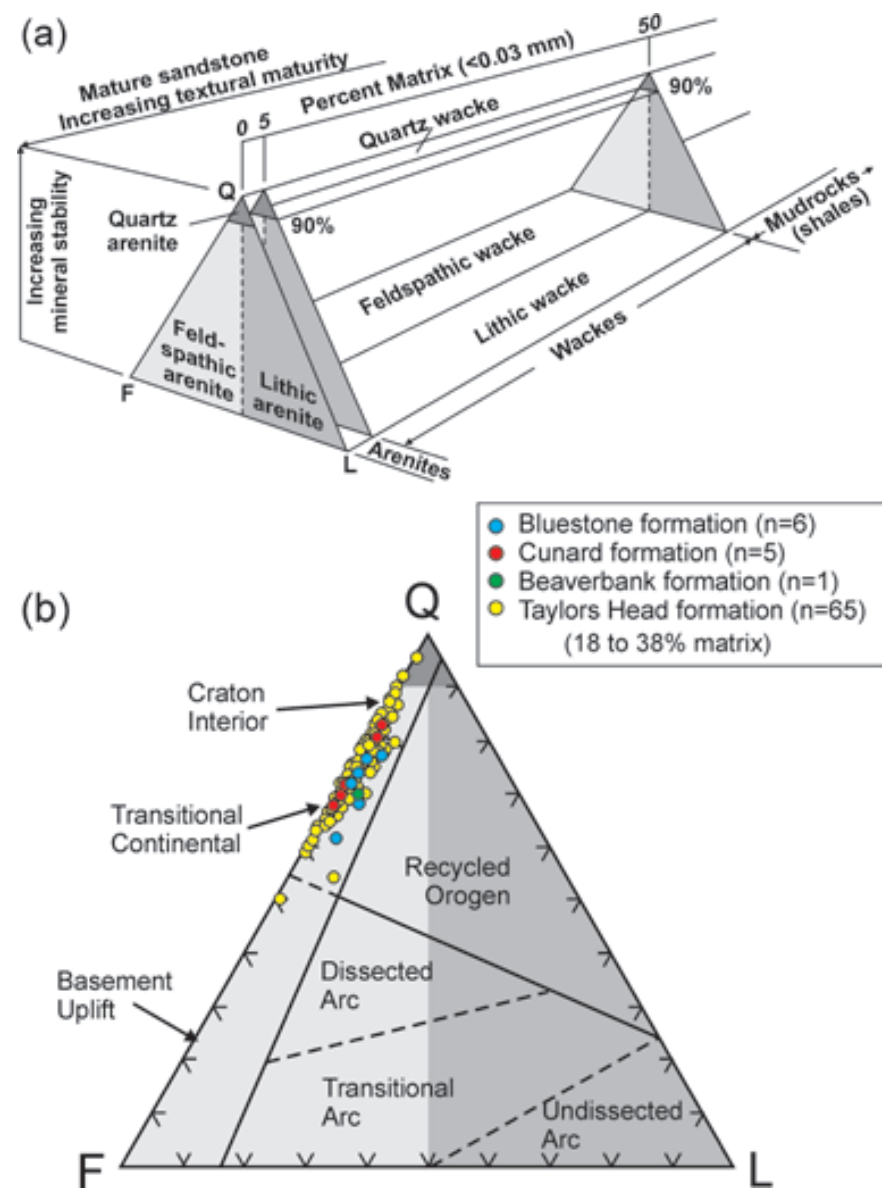

Fig. 4. (a) Classification of sandstone based on modal quartz (Q), feldspar (F), lithic fragments (L), and proportion of matrix, after Boggs (2001). (b) Classification and provenance for samples from the Goldenville and Halifax groups with $<5 \%$ and $<50 \%$ matrix. Shaded classification fields from (a) are shown on (b). Provenance fields are after Dickinson $e t$ al. (1983). About 500 to 1000 points were counted in each thin section, using a modified version of the Gazzi-Dickinson method, which includes counting grains where they form part of a lithic fragment to eliminate apparent variations in the composition of samples resulting only from differences in grain size (Ingersoll et al., 1984).

Trace amounts of zircon, titanite, and tourmaline also occur. Lithic fragments are rare and are dominantly quartzite.

Calcite $\left(\mathrm{CaCO}_{3}\right)$, and to a lesser degree dolomite $[\mathrm{Ca}$, $\left.\mathrm{Mg}\left(\mathrm{CO}_{3}\right)_{2}\right]$, occur in nodules and as minor cement in metasandstone of the Taylors Head and Bluestone formations. Calcite nodules and laminations also occur within the slate of the Beaverbank and Bluestone formations, and rhodochrosite $\left(\mathrm{MnCO}_{3}\right)$ has been documented in units equivalent to the Beaverbank formation (O'Beirne-Ryan 1996). Ankerite $\left[\mathrm{Ca}(\mathrm{Fe}, \mathrm{Mg}, \mathrm{Mn})\left(\mathrm{CO}_{3}\right)_{2}\right]$ is not common but has been noted in metasandstone units within gold districts of the Goldenville Group (MacDonald 1998). 


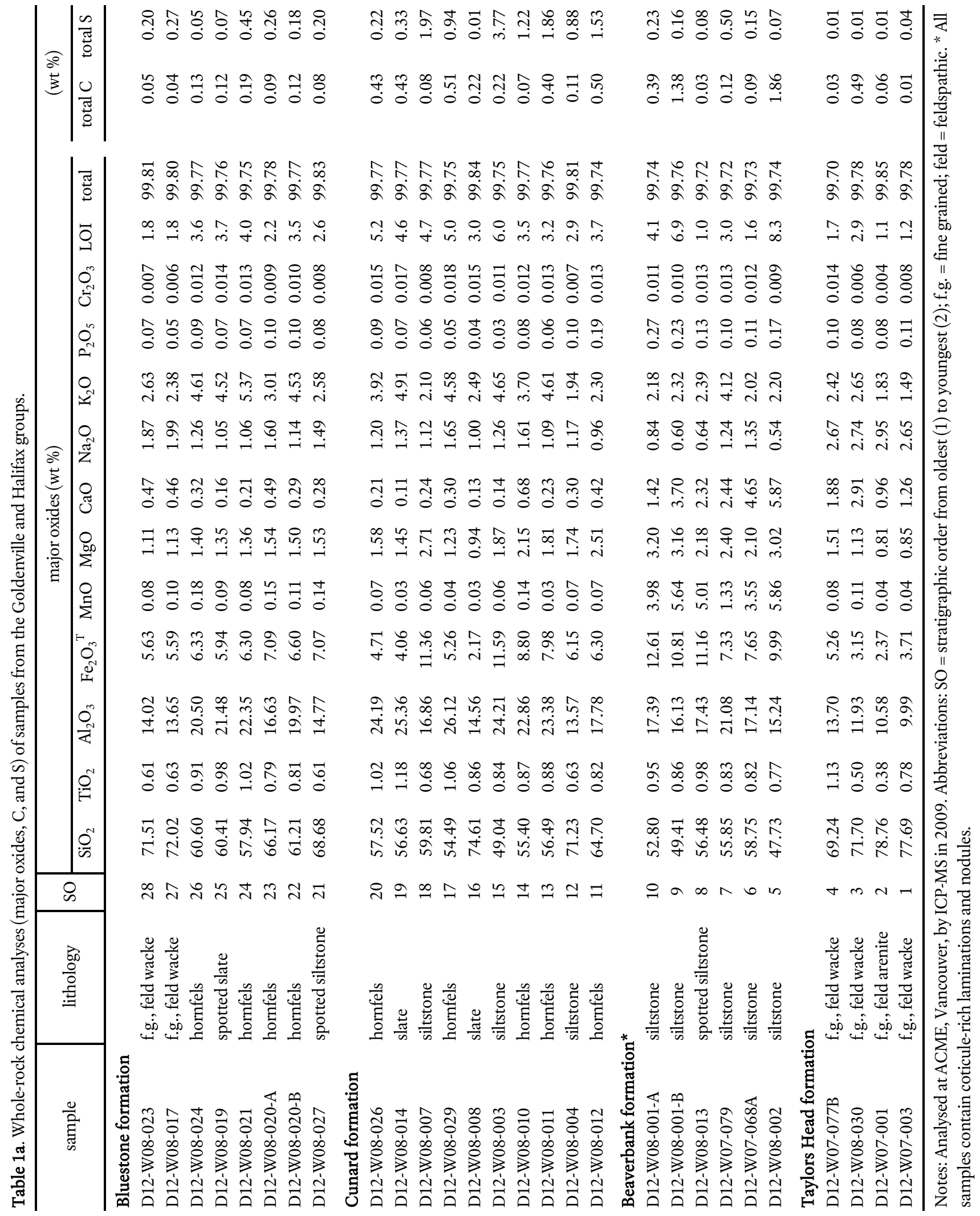




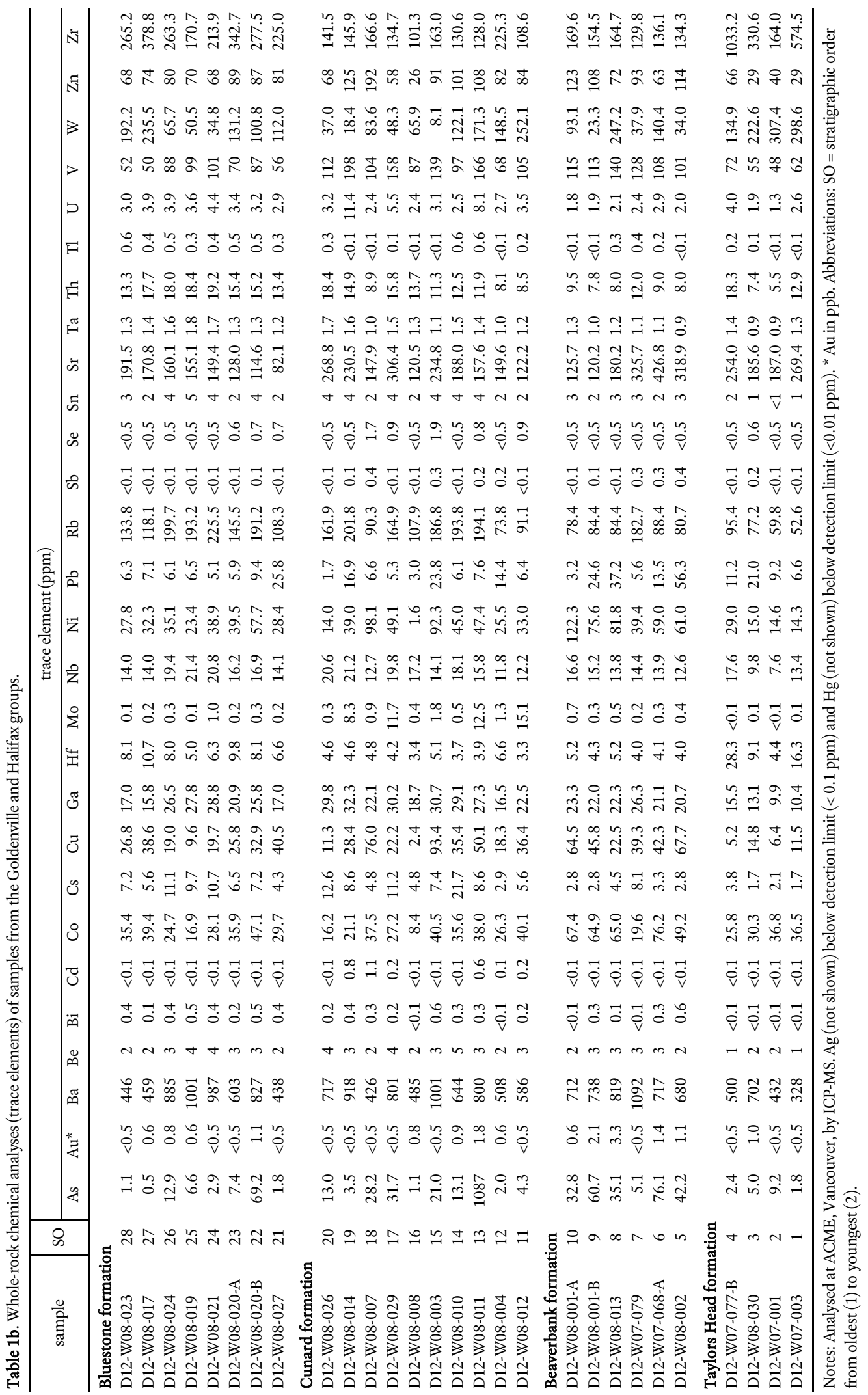


Table 2. Analyses of ARD potential in HRM by the BC-RIT analysis. For comparison total S analysis from the portable XRF and ACME are included.

\begin{tabular}{|c|c|c|c|c|c|c|c|c|c|}
\hline Sample & $\mathrm{SO}$ & $\begin{array}{c}\text { XRF } \\
\text { S (Total) } \\
\text { wt. } \%\end{array}$ & $\begin{array}{c}\text { ACME } \\
\text { S (Total) } \\
\text { wt. } \%\end{array}$ & $\begin{array}{c}\text { BC-RIT } \\
\text { S (Total) } \\
\text { wt. } \%\end{array}$ & $\begin{array}{c}\text { S (Sulphide) } \\
\text { wt. } \%\end{array}$ & $\begin{array}{c}\mathrm{APP} \\
\mathrm{H}_{2} \mathrm{SO}_{4} \\
\mathrm{~kg} / \mathrm{t}\end{array}$ & $\begin{array}{c}\mathrm{ACA} \\
\mathrm{H}_{2} \mathrm{SO}_{4} \\
\mathrm{~kg} / \mathrm{t}\end{array}$ & Difference & Problem \\
\hline \multicolumn{10}{|c|}{ Bluestone formation } \\
\hline D12-W08-023 & 23 & 0.291 & 0.20 & 0.195 & 0.174 & 5.323 & 5.386 & 0.063 & Maybe \\
\hline D12-W08-017 & 22 & 0.525 & 0.27 & 0.289 & 0.275 & 8.412 & 6.359 & -2.054 & Yes \\
\hline D12-W08-024 & 21 & 0.125 & 0.05 & 0.068 & 0.057 & 1.744 & 5.861 & 4.117 & No \\
\hline D12-W08-019 & 20 & 0.061 & 0.07 & 0.059 & 0.052 & 1.591 & 5.143 & 3.552 & No \\
\hline D12-W08-021 & 19 & 0.555 & 0.45 & 0.509 & 0.501 & 15.326 & 6.830 & -8.496 & Yes \\
\hline D12-W08-020-A & 18 & 0.172 & 0.26 & 0.262 & 0.241 & 7.372 & 7.085 & -0.287 & Yes \\
\hline D12-W08-020-B & 17 & 0.107 & 0.18 & 0.200 & 0.182 & 5.567 & 5.870 & 0.303 & Maybe \\
\hline D12-W08-027 & 16 & 0.255 & 0.20 & 0.227 & 0.201 & 6.149 & 4.410 & -1.739 & Yes \\
\hline \multicolumn{10}{|l|}{ Cunard formation } \\
\hline D12-W08-026 & 15 & 0.305 & 0.22 & 0.228 & 0.174 & 5.323 & 4.157 & -1.166 & Yes \\
\hline D12-W08-014 & 14 & 0.557 & 0.33 & 0.342 & 0.298 & 9.116 & 3.176 & -5.940 & Yes \\
\hline D12-W08-007 & 13 & 1.792 & 1.97 & 1.880 & 1.805 & 55.215 & 1.960 & -53.255 & Yes \\
\hline D12-W08-029 & 12 & 1.119 & 0.94 & 0.933 & 0.914 & 27.959 & 14.927 & -13.032 & Yes \\
\hline D12-W08-008 & 11 & 0.05 & 0.01 & 0.054 & 0.042 & 1.285 & 7.827 & 6.543 & No \\
\hline D12-W08-003 & 10 & 3.733 & 3.77 & 3.415 & 3.318 & 101.498 & 2.687 & -98.811 & Yes \\
\hline D12-W08-010 & 9 & 1.368 & 1.22 & 1.160 & 1.126 & 34.444 & 6.108 & -28.336 & Yes \\
\hline D12-W08-011 & 8 & 1.971 & 1.86 & 1.830 & 1.803 & 55.154 & 0.976 & -54.178 & Yes \\
\hline D12-W08-004 & 7 & 0.818 & 0.88 & 0.867 & 0.836 & 25.573 & 3.430 & -22.144 & Yes \\
\hline D12-W08-012 & 6 & 1.782 & 1.53 & 1.454 & 1.339 & 40.960 & 5.134 & -35.826 & Yes \\
\hline \multicolumn{10}{|c|}{ Beaverbank formation } \\
\hline D12-W08-001-B & 5 & 0.347 & 0.16 & 0.154 & 0.139 & 4.252 & 93.468 & 89.216 & No \\
\hline D12-W08-013 & 4 & 0.26 & 0.08 & 1.404 & 1.399 & 42.795 & 9.615 & -33.180 & Yes \\
\hline D12-W08-002 & 3 & 0.263 & 0.07 & 0.058 & 0.042 & 1.285 & 147.137 & 145.852 & No \\
\hline \multicolumn{10}{|c|}{ Taylors Head formation } \\
\hline D12-W08-030 & 2 & 0.017 & 0.01 & 0.012 & 0.008 & 0.245 & 36.011 & 35.767 & No \\
\hline D12-W07-003 & 1 & 0.019 & 0.04 & 0.041 & 0.034 & 1.040 & 1.363 & 0.323 & Maybe \\
\hline
\end{tabular}

Notes: Abbreviations: $\mathrm{SO}=$ stratigraphic order from oldest (1) to youngest (2); $\mathrm{APP}=$ acid producing potential; $\mathrm{ACA}=\mathrm{acid}$ consuming ability.

Magnetite and minor ilmenite are the main magnetic minerals in the metasandstone and metasiltstone beds (King 1997; Pelley 2007). They form small (0.1-0.2 mm), inclusion-rich to inclusion poor, euhedral crystals in the matrix and are metamorphic in origin; however, the more magnetic beds contain magnetite up to $2 \mathrm{~mm}$ in diameter, which is likely partly detrital in origin (Pelley 2007).

Cubic pyrite (1 to $2 \mathrm{~cm}$ in diameter) is typically rare in metasandstone of the Taylors Head formation but more abundant in the slaty rocks and metasandstone of the Cunard formation and locally is present in the Bluestone formation at lower metamorphic grades. Based on petrographic evidence the pyrite predates the regional foliation (e.g., Hicks 1996).

Pyrrhotite is not common in metasandstone beds in the Taylors Head formation but does occur locally with magnetite in the minor interbedded metasiltstone and slate. In the Beaverbank formation pyrrhotite typically occurs in the cores of spessartine garnet grains (e.g., Fox et al. 1997; White 2010a). Pyrrhotite, along with pyrite, is common in the Cunard for- mation (e.g., Pasava et al. 1995) and locally present in the Bluestone formation. It can occur as relatively inclusion-free porphyroblasts but is typically inclusion-rich, flattened parallel to foliation, and elongate parallel to the intersection lineation and regional fold axis, indicating it grew during regional chlorite-grade metamorphism that was synchronous with regional deformation.

As metamorphic grade increases toward the contact with the South Mountain Batholith, the matrix minerals in the metasandstone beds are comprised of coarser grained white mica and decussate biotite and ultimately poikiloblastic cordierite at the contact. In these less aluminous metasandstone beds, andalusite and sillimanite are rare. In the pelitic units of the Taylors Head and Beaverbank formations the matrix material also becomes coarser grained and, like in the metasandstone, decussate biotite appears. Closer to the contact with the South Mountain Batholith, biotite content increases and ovoid cordierite appears; it has typically been weathered out leaving tiny voids in the rock. Plagioclase compositions become in- 
creasingly Ca-rich with higher An contents (up to $\mathrm{An}_{50}$ ) at the contact with the South Mountain Batholith (Mahoney 1996; White 2003; Clarke et al. 2009).

Jamieson et al. (2005 a, b) documented a change in the opaque mineralogy with increasing metamorphic grade where rutile and pyrite in the outer aureole are replaced by ilmenite and pyrrhotite closer to the contact. As noted by Clarke et al. (2009), pyrrhotite is the dominant sulphide in the contact aureole adjacent to the $\mathrm{SMB}$, forming up to 15 modal \% in some layers in the Halifax Group (Betts-Robertson 1998). Like in the lower grade metamorphic rocks, pyrrhotite remains flattened and elongate parallel to the relict foliation and intersection lineation. The pyrrhotite is typically anhedral and contains abundant inclusions of quartz, sheet silicates, Fe-Ti oxides, and other sulphide minerals that define inclusion trails parallel to the relict foliation in the matrix (i.e., Fox et al. 1997; Clarke et al.2009). In contrast, pyrrhotite in the metasandstone beds of the Cunard formation is cubic (up to $1 \mathrm{~cm}$ in diameter) because it has pseudomorphed pyrite (Clarke et al. 2009).

In the shear zone at the contact between the SMB and country rocks, the intersection lineation becomes steeper and forms a mineral lineation defined by elongate quartz+biotite \pm cordierite aggregates and elongate calc-silicate nodules in the metasandstone or boudinaged andalusite and elongate pyrrhotite in the pelitic rocks (Culshaw and Bhatnagar 2001; White et al. 2008). In contrast to the Taylors Head formation, the main magnetic mineral is pyrrhotite in the Beaverbank, Cunard, and Bluestone formations. Other minor sulphide minerals associated with pyrrhotite, typically as inclusions, include chalcopyrite, sphalerite, arsenopyrite, and galena. Although pyrrhotite is the dominant sulphide in some layers (Fox et al. 1997: Clarke et al. 2009), no samples collected in the study contain over 5 modal \% total sulphide minerals.

\section{South Mountain Batholith}

The Quarry Lake granodiorite (Fig. 2) is medium- to coarsegrained, equigranular to megacrystic, with alkali feldspar and less abundant plagioclase megacrysts. It has abundant metasedimentary xenoliths of the Goldenville and Halifax groups. Quartz forms anhedral to subhedral grains in the groundmass but in places forms subhedral megacrysts. Plagioclase is typically in the groundmass as subhedral crystals displaying normal to oscillatory zoning, and ranging in composition from An 5-35, whereas alkali feldspar occurs as euhedral perthitic megacrysts (e.g., MacDonald 2001). Biotite is mainly subhedral to euhedral in the groundmass and forms up to 25 modal percent. Muscovite, cordierite, and garnet occur in trace amounts. The monzogranite and leucomonzogranite units to the southwest (Fig. 1) display textures similar to the granodiorite but contain more muscovite and cordierite and less biotite (MacDonald 2001).

Pyrrhotite and chalcopyrite are the main sulphide minerals in the Quarry Lake granodiorite, together with trace amounts of sphalerite, galena, arsenopyrite, and molybdenite which typically occur as inclusions in the pyrrhotite (e.g., Clarke et al.
2009). Although the pyrrhotite may retain a similar flattened morphology as in the adjacent country rock, it is inclusionfree, small ( $<2 \mathrm{~mm}$ in size), and in some samples appears to be interstitial. The overall modal abundance of sulphide minerals in the batholith is less than $2 \%$, considerably less than in the adjacent country rocks but can be several volume $\%$ of the granite at the contact (Clarke et al. 2009). No sample of granitoid rock collected during the present study contains over $1 \%$ sulphide minerals.

A detailed description of sulphide mineral textures and chemistry in the contact aureole and adjacent granitoid rocks of the South Mountain Batholith was provided by Clarke et al. (2009).

\section{RESULTS AND DISCUSSION}

\section{Lithogeochemistry}

Major element oxide and trace element data can provide useful information on ARD prediction. Because the ARD behaviour of a rock is depended on its mineral assemblage, the effects of changes in mineralogical composition on acid-rock generation and buffering reactions must be considered when predicting ARD. Because the portable XRF does not measure elements lighter than $\mathrm{Na}$, data from ACME is used for $\mathrm{SiO}_{2}$, $\mathrm{Al}_{2} \mathrm{O}_{3}, \mathrm{~K}_{2} \mathrm{O}, \mathrm{Na}_{2} \mathrm{O}$, and $\mathrm{Fe}_{2} \mathrm{O}_{3}{ }^{\mathrm{T}}$ plots (Table 1a, Fig. 5).

Variations in $\mathrm{SiO}_{2}$ content and $\mathrm{SiO}_{2} / \mathrm{Al}_{2} \mathrm{O}_{3}$ ratio can be linked to the relative proportions of quartz, feldspar, and matrix minerals in the samples. White and Barr (2010) demonstrated this relationship for metasedimentary rocks in the Goldenville and Halifax groups in southwestern Nova Scotia. In the present study, petrographic data also were compared to their chemical compositions (Table 1a) and the results indicate that the boundary between sandstone and siltstone/mudstone is at $65 \%$ wt. $\% \mathrm{SiO}_{2}$ with a corresponding $\mathrm{SiO}_{2} / \mathrm{Al}_{2} \mathrm{O}_{3}$ ratio of 3.5 (Fig. 5a), identical to the results of White and Barr (2010) from elsewhere in Meguma terrane. Samples with more than 65\% $\mathrm{SiO}_{2}$ when plotted on the chemical discrimination diagram of Herron (1988) are wacke to litharenite, whereas those with less than $65 \% \mathrm{SiO}_{2}$ are mainly shale to Fe-rich shale (Fig. 5 b). On the chemical classification of sandstone diagram of Pettijohn et al. (1987), samples with more than $65 \% \mathrm{SiO}_{2}$ plot mainly in the litharenite field (Fig. 5c).

Metasandstone, siltstone, slate, and calc-silicate nodules were analyzed in each formation and plotted according to stratigraphic position against several chemical parameters (Figs. 6 and 7). The Taylors Head formation is typically low in $\mathrm{CaO}$ and $\mathrm{MnO}$ (Fig. 6a, b) and there is no difference between metasandstone and metasiltstone/slate. However, metasandstone samples with a carbonate matrix/cement are slightly higher in $\mathrm{CaO}$ with calc-silicate nodules having up to $23 \mathrm{wt}$. $\% \mathrm{CaO}$ and no significant $\mathrm{MnO}$ (Fig. 6a, b). $\mathrm{Fe}_{2} \mathrm{O}_{3}{ }^{\mathrm{T}}$ tends to be higher in the metasiltstone and slate samples than in metasandstone samples (Appendix A-D). The metasiltstone-rich Beaverbank formation is higher in $\mathrm{CaO}$ and $\mathrm{MnO}$ with the metasandstone 
having the lowest concentrations and the metasiltstone and slate slightly higher (Appendix A, B). The coticule nodules and layers are significantly higher in $\mathrm{MnO}, \mathrm{CaO}$, and $\mathrm{Fe}_{2} \mathrm{O}_{3}{ }^{\mathrm{T}}(\mathrm{Fig}$. $6 \mathrm{a}, \mathrm{b}, \mathrm{c})$ but that correlation is not $1: 1$ as some metasiltstone samples with high $\mathrm{CaO}$ are low in $\mathrm{MnO}$ and $\mathrm{Fe}_{2} \mathrm{O}_{3}{ }^{\mathrm{T}}$. In contrast, all samples in the overlying Cunard formation display low $\mathrm{CaO}$ and $\mathrm{MnO}$ but $\mathrm{Fe}_{2} \mathrm{O}_{3}{ }^{\mathrm{T}}$ remains high. Metasandstone and metasiltstone samples from the Bluestone formation are somewhat similar in $\mathrm{CaO}, \mathrm{MnO}$, and $\mathrm{Fe}_{2} \mathrm{O}_{3}{ }^{\mathrm{T}}$ to those from the underlying Cunard formation; however, the calc-silicate nodules are significantly higher in $\mathrm{CaO}$ and only slightly higher in $\mathrm{MnO}$ and $\mathrm{Fe}_{2} \mathrm{O}_{3}{ }^{\mathrm{T}}$ (Fig. 6a, b).

Total weight percent sulphur also varies with stratigraphic position and rock type, with median values of 0.04 in the Taylors Head formation, 0.32 in the Beaverbank formation, 1.29 in the Cunard formation, 0.17 in the Bluestone formation, and 0.01 in the granitoid rocks of the South Mountain Batholith (Fig. 7a; Appendix A-E). The higher values in the Beaverbank, Cunard, and Bluestone formations are attributed to abundant pyrrhotite. Some of the highest values $(>5 \mathrm{wt}$. \%) are in hornfelsic samples from around the South Mountain Batholith. Typically there is a positive correlation between total sulphur and total metals $(\mathrm{Cu}+\mathrm{Pb}+\mathrm{Zn})$ (e.g., Hammarstrom et al. 2003) but only the Cunard formation displays this trend (Fig. 7b). However, $\mathrm{Pb}, \mathrm{Zn}, \mathrm{Cu}$, and As show no significant differences with stratigraphic position and all of the anomalous samples are located in the contact aureole of the South Mountain Batholith (Fig. 7c, d, e, f).

The chemical change at the contact between the Taylors Head and Beaverbank formations marks a dramatic and rapid change in the original seawater chemistry where conditions were favourable for deposition of $\mathrm{Ca}, \mathrm{Mn}, \mathrm{Fe}$, and S. Under anoxic conditions Mn-oxide served as the oxidant, thereby leading to the eventual precipitation of manganese carbonate near the sediment-water contact (Graves and Zentilli 1988). These conditions are also favourable for sulphide mineral precipitation. The Beaverbank formation contains some of the highest total carbon values compared to the other formations (Table 1a).

The Beaverbank formation and equivalent Moshers Island formation elsewhere in the Meguma terrane are also enriched in $\mathrm{Pb}, \mathrm{Zn}, \mathrm{Cu}$, and $\mathrm{As}$ (Graves and Zentilli 1988); however, the Taylors Head, Cunard, and Bluestone formations are also locally enriched in these elements (e.g., White 2010b). In the HRM area this enrichment appears to be associated with contact metamorphic effects from the South Mountain Batholith as indicated by the increased presence of chalcopyrite, galena, sphalerite, and arsenopyrite in the contact aureole (Clarke et al. 2009).

\section{Acid generation prediction}

In Nova Scotia, the Sulphide Bearing Material Disposal Regulations state that rocks having sulphide sulphur contents equal to or greater than 0.4 weight \% must be considered as hazardous ARD material. The portable XRF results, like the results from Acme Analytical Laboratories, are presented as
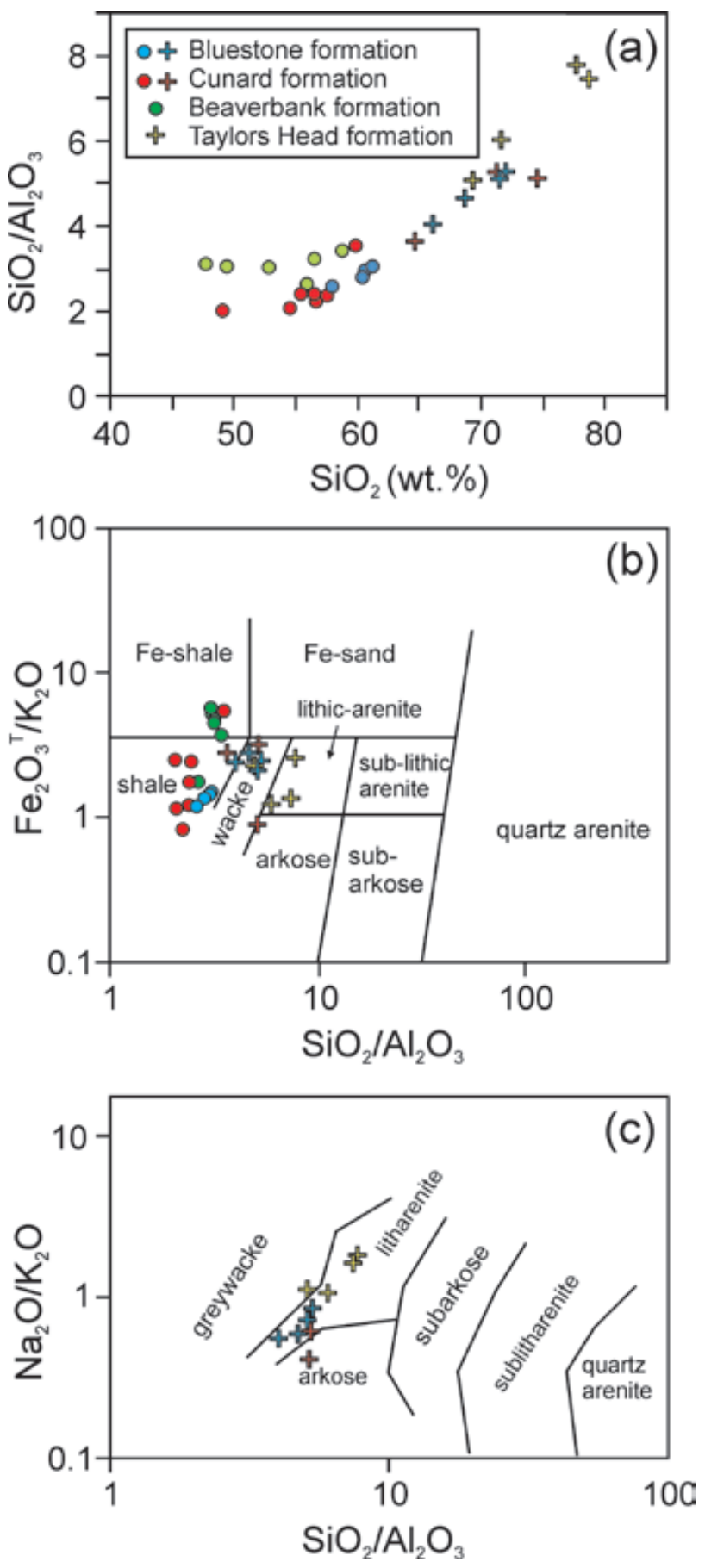

Fig. 5. (a) Plot of $\mathrm{SiO}_{2}$ against $\mathrm{SiO}_{2} / \mathrm{Al}_{2} \mathrm{O}_{3}$ where classification as sandstone (plus symbols) or siltstone/mudstone (circles) is based on petrographic study. (b) Chemical classification using $\mathrm{Fe}_{2} \mathrm{O}_{3}{ }^{\mathrm{T}} / \mathrm{K}_{2} \mathrm{O}$ versus $\mathrm{SiO}_{2} / \mathrm{Al}_{2} \mathrm{O}_{3}$. Fields are from Herron (1988). (c) Chemical classification using $\mathrm{Na}_{2} \mathrm{O} / \mathrm{K}_{2} \mathrm{O}$ versus $\mathrm{SiO}_{2} / \mathrm{Al}_{2} \mathrm{O}_{3}$. Fields are from Pettijohn et al. (1987).

total weight \% sulphur which, based on the data in Table 2, is about $17 \%$ higher than total sulphide sulphur, except in samples from the Cunard formation where the ratio is almost 1:1 (Table 2). Although assigning all sulphur to sulphides is per- 

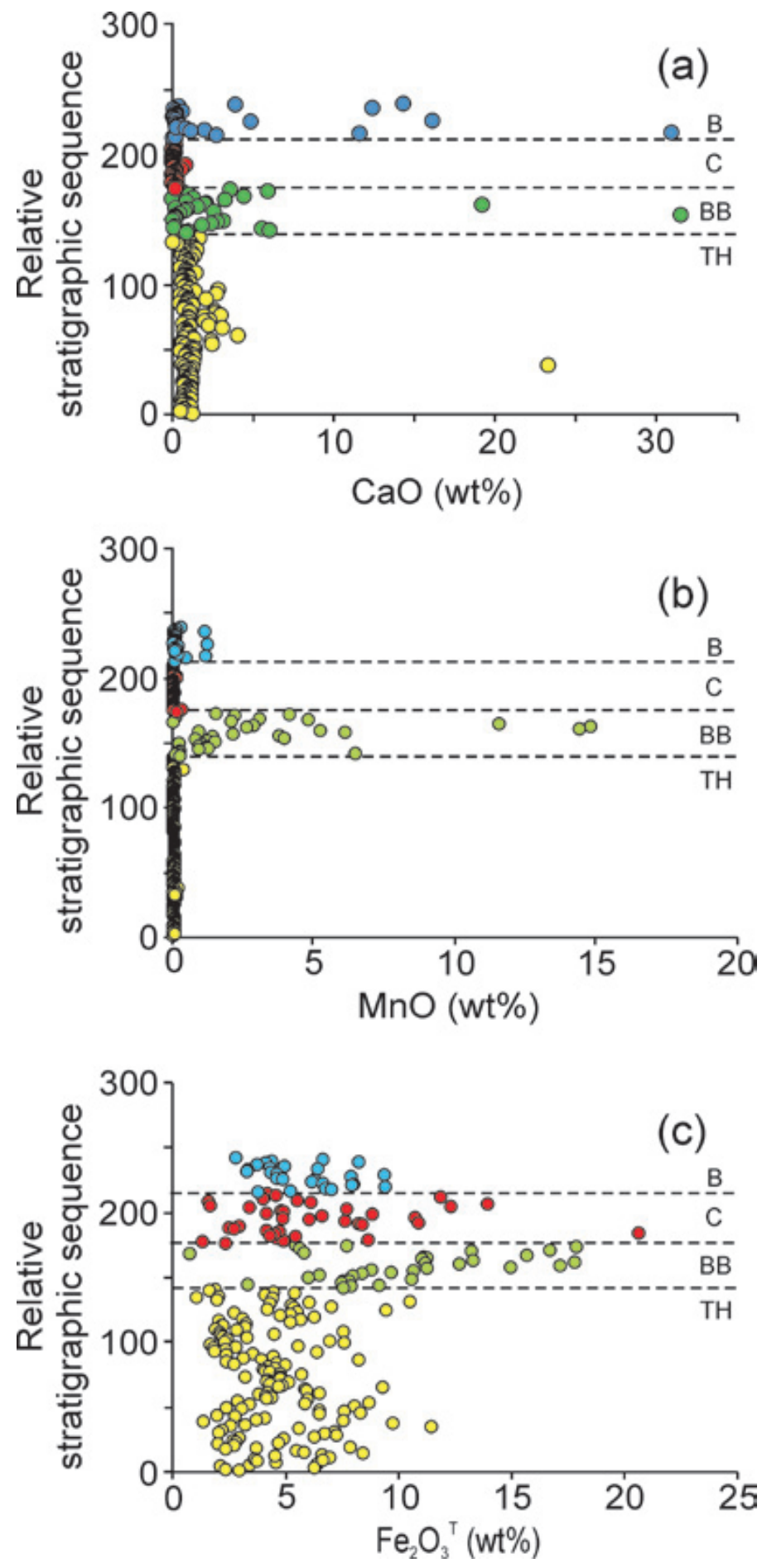

Fig. 6. Plots of selected chemical parameters against relative stratigraphic position: (a) $\mathrm{CaO}$, (b) $\mathrm{MnO}$, and (c) $\mathrm{Fe}_{2} \mathrm{O}_{3}{ }^{\mathrm{T}}$ in the Goldenville and Halifax groups. Abbreviations: $\mathrm{B}=$ Bluestone formation; $\mathrm{C}=$ Cunard formation; $\mathrm{BB}=$ Beaverbank formation; TH = Taylors Head formation. Symbols are as in Fig. 3.

haps overly conservative as it ignores contributions from nonacid generating phases (e.g., sulphates and organic matter), the total weight \% sulphur and total sulphide sulphur can be considered interchangeable; hence, a rock with total sulphur content equal to or greater than 0.47 can be considered hazardous (Fig. 7a). However, this parameter does not take into account the possible neutralizing capacities of minerals in the rock (Weber et al.2005) or the varying reactivities of different sulphide minerals.

The most important acid neutralizing minerals in the Goldenville and Halifax groups are calcite and dolomite and, to a much lesser extent, rhodochrosite and ankerite. The neutralizing power of feldspar varies considerably, depending on its composition. Altered (i.e., sericitized) feldspar has much less neutralizing power than its unaltered or carbonatized equivalents. Potassium-rich feldspar (orthoclase/microcline) and $\mathrm{Na}$-rich plagioclase (albite) have less neutralizing power than the more Ca-rich plagioclase (anorthite). The metasandstone in the lower grade regional metamorphic rocks typically contains albitic plagioclase; however, in the contact metamorphic aureole plagioclase (10-40 modal \%) is typically more Ca-rich (oligoclase to andesine) which adds to the neutralizing power. Minerals containing $\mathrm{Mg}$ (biotite and chlorite) also contribute to buffering ARD, but play a minor role (Weber et al. 2005). In the Goldenville and Halifax groups it is likely that the abundance of plagioclase and its alteration products, along with carbonate minerals, largely determine the neutralizing power in high sulphur samples. In comparison, the granitoid rocks of the SMB have total sulphur less than 0.20 weight $\%$ and pose no apparent ARD risk (Fig. 8; Appendix E).

The potential for acid generation is dependent on the ratio of acid-producing potential (APP) to acid-consuming ability (ACA). Following the legally binding British Columbia Research Initial Test the neutralizing power of 23 samples has been calculated (Table 2) and plotted (Fig. 9a). A 1:1 ratio (acid/ base) is plotted and assumes that the tested samples that plot below this ratio are net acid consumers (e.g., Schoeffer and Clawson 1996). However, Lawrence and Scheske (1997) noted that different mineral groups have different relative reactivities (i.e., carbonate minerals react faster than feldspar minerals), and hence the control on neutralization varies with mineralogy and a more suitable value for the neutralizing potential is 0.54 . Because it is difficult to predict the short- and long-term acid generation potential of a rock unit a "zone of uncertainty" was defined between the 1:1 and 1:2 gradient lines (Fig. 9a, b) (Bell and Bullock 1996; Campbell et al. 2001).

Total $\mathrm{S}$ wt $\%$ versus $\mathrm{CaO}$ wt $\%$ can be considered equivalent to APP/ACA in a theoretical sense (e.g., Downing and Madeisky 1997) and it has been shown that data from the portable $\mathrm{XRF}$ is comparable to Acme Analytical Laboratories and British Columbia Research Initial Test results (Fig. 3). Hence, a plot of total $\mathrm{S}$ wt. \% versus $\mathrm{CaO}$ wt. \% for data collected from the portable XRF can be used with a significant degree of confidence as a first approximation for acid generating potential of the rock.

Figure $9 \mathrm{~b}$ shows a wide distribution of sample populations which indicates that three units are potentially acid producers (Bluestone, Cunard, and Beaverbank formations), and two units are non-acid producing (Taylors Head formation and South Mountain Batholith). About $97 \%$ of the samples col- 
lected from the Cunard formation are potential acid producers with an APP/ACA and S/CaO ratios of $>1.0$ (Fig, 9a, b) and a high median total sulphur content of $1.31 \%$. About $3 \%$ of the samples are non-acid producers. In comparison, $26 \%$ of the samples in the stratigraphically higher Bluestone formation and
$24 \%$ of the samples from the underlying Beaverbank formation are potential acid producers with average total sulphur of $0.30 \%$ and $0.90 \%$, respectively. However, about half (50-55\%) of the samples from these two formations lie in the zone of uncertainty and hence can be acid producers under the right
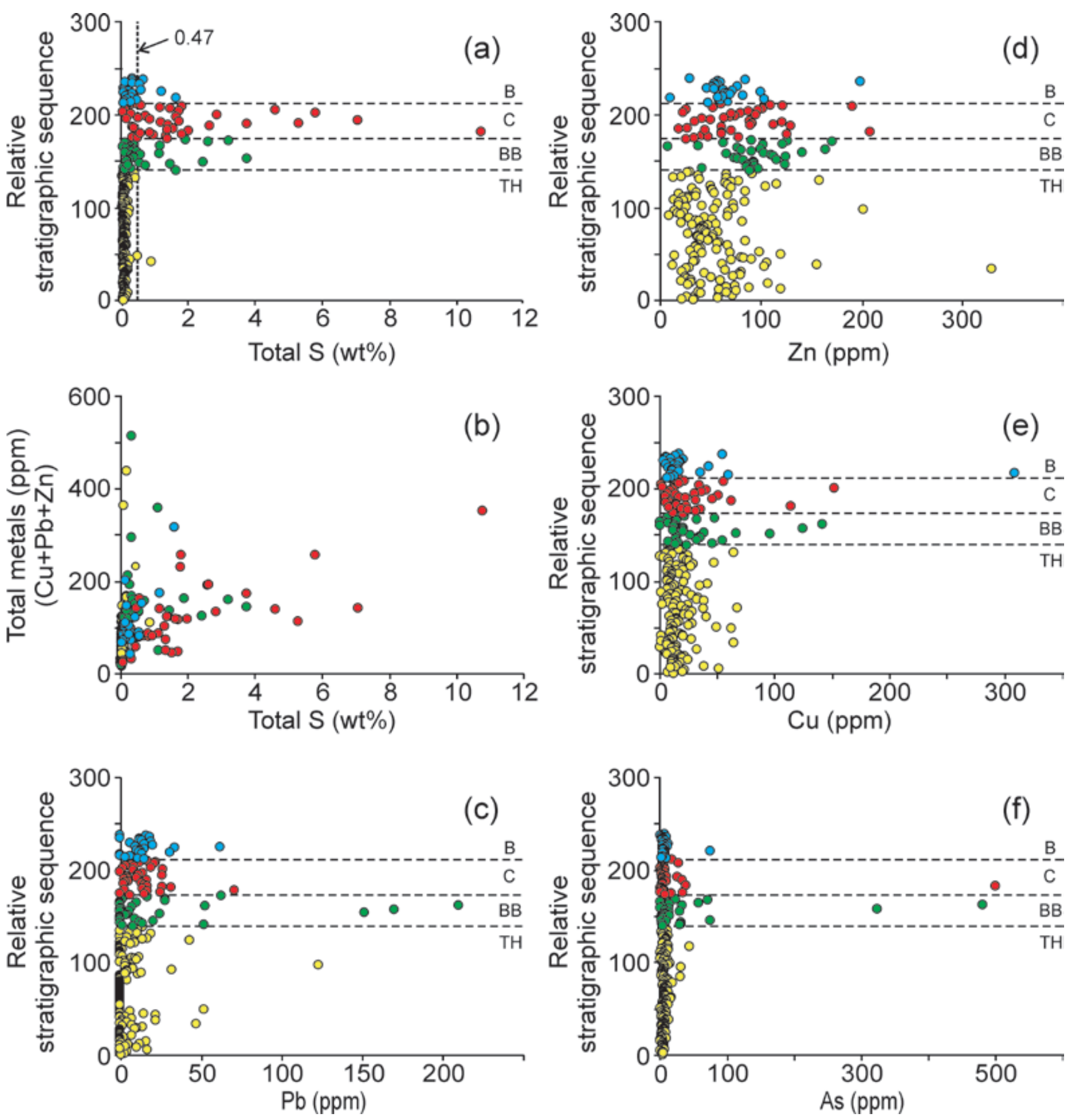

Fig. 7. Plots of selected chemical parameters against relative stratigraphic position: (a) $\mathrm{S}$, (c) $\mathrm{Pb},(\mathrm{d}) \mathrm{Zn}$, (e) $\mathrm{Cu}$, and (f) As, and (b) plot of total $\mathrm{S}$ against total metals in the Goldenville and Halifax groups. Abbreviations: $\mathrm{B}=\mathrm{Bluestone}$ formation; $\mathrm{C}$ $=$ Cunard formation; $\mathrm{BB}=$ Beaverbank formation; $\mathrm{TH}=$ Taylors Head formation. Symbols are as in Fig. 3 . 


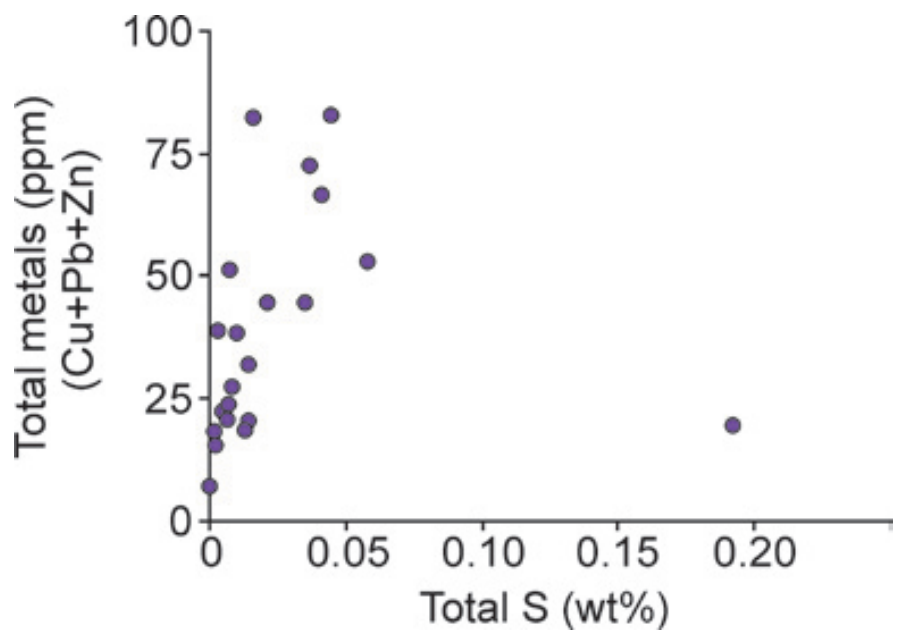

Fig. 8. Plot of total S against total metals in the South Mountain Batholith.

conditions. The high sulphur percentage and acid producing potential in the Bluestone, Cunard, and Beaverbank formations is consistent with major basin-wide stagnation in which anoxic conditions existed during the depositional history of these formations (Waldron 1987; Graves and Zentilli 1988). The high proportion of acid-producing rocks in the Cunard formation can be directly linked to the low acid-buffering $\mathrm{CaO}$ content (median $=0.09 \mathrm{wt}$ \%) compared to the Bluestone and Beaverbank formations (median $=0.39$ and $1.29 \mathrm{wt} . \%$, respectively) (Appendix A-C).

About $99 \%$ of the samples from the Taylors Head formation are non-acid producing (Fig. 9b) and have a low total sulphur content (median $=0.04$ wt. \%) $($ Appendix D). One sample (D12-W09-101) that is a potential acid producer has low total sulphur (0.023 wt. \%) and low $\mathrm{CaO}(0.01$ wt. \%) and is one of two samples that is classified as quartz arenite (Fig. 4b) and hence is not likely to produce acid due to the high quartz content. The other sample classified as quartz arenite (D12W07-015) is a spotted metasiltstone which contains $0.86 \mathrm{wt}$. $\%$ sulphur (Appendix D). It is from a thin $(<20 \mathrm{~cm}$ thick) bed within a massive metasandstone bed and, although this sample has the potential to produce acid, the effects would likely be diluted by the surrounding non-acid producing metasandstone.

About $95 \%$ of the granitoid samples from the South Mountain Batholith are non-acid producing (Fig. 9b) and have the lowest average total sulphur content $(0.017 \mathrm{wt} \%)$ of all the units sampled (Appendix E). One sample (CW-270B) plots in the zone of uncertainty and has a total sulphur content of 0.859 wt. \%. It has an elevated sulphur percentage compared to the other granitoid samples because it is a pyrite-bearing aplite-pegmatite dyke cutting the South Mountain Batholith. Because this is a minor unit the acid-producing potential is considered as low.

A useful application of susceptibility measurements is to determine the presence of sulphide-bearing minerals in outcrop. High magnetic susceptibility measurements are indicative of the presence of ferromagnetic and paramagnetic minerals
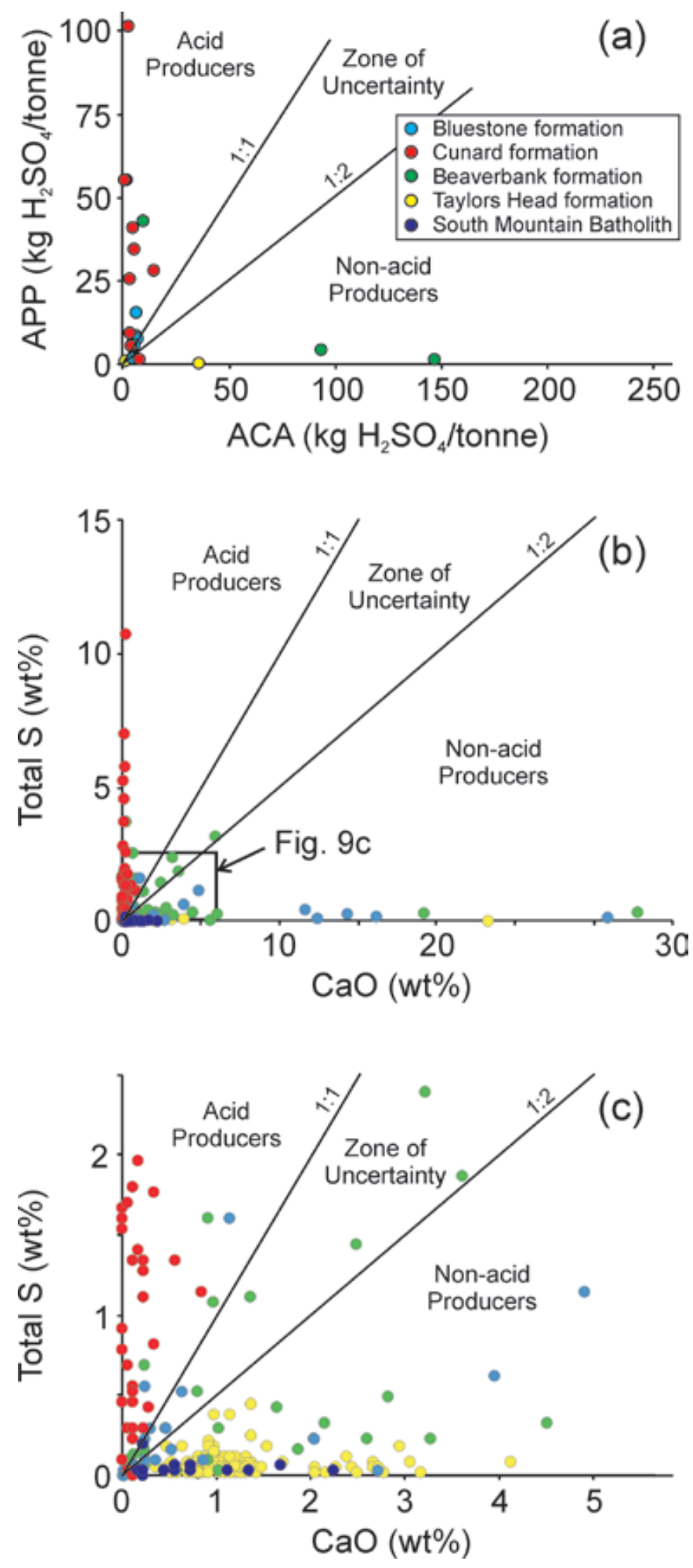

Fig. 9. (a) Plot of acid-producing potential (APP) against acid-consuming ability (ACA) using results from the British Columbia Research Initial Test. (b) Plot of total $S$ against $\mathrm{CaO}$ using results from the portable XRF. Area of Fig 9c is shown in box. (c) Close-up of data in box shown at origin in Fig. 9b. 


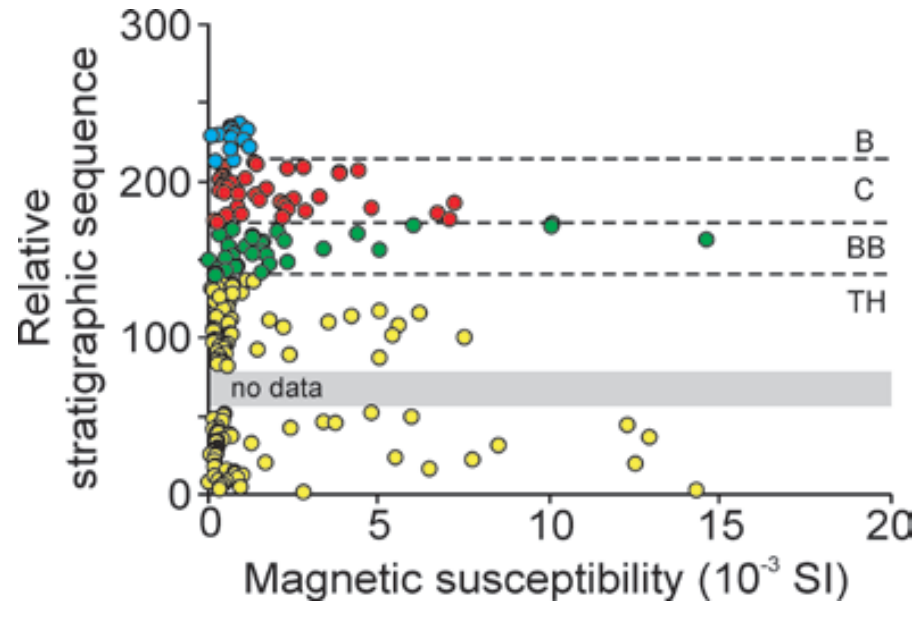

Fig. 10. Plot of magnetic susceptibility against stratigraphic position in the Goldenville and Halifax groups. Abbreviations: $\mathrm{B}=$ Bluestone formation; $\mathrm{C}=$ Cunard formation; $\mathrm{BB}$ $=$ Beaverbank formation; $\mathrm{TH}=$ Taylors Head formation. Symbols are as in Fig. 3.

(e.g., King 1997; Howells and Fox 1998; Fitzgerald and Goodwin 2005). In the Taylors Head formation the high magnetic susceptibility measurements are due to the presence of magnetite and to a lesser degree ilmenite. In contrast, the high readings in the Beaverbank, Cunard, and Bluestone formations are due to the presence of pyrite in the lower metamorphic grade rocks and pyrrhotite in the higher metamorphic grade contact aureole of the South Mountain Batholith(Fig. 10). The susceptibility data aid in delineating problematic, potentially acid-producing units before excavation takes place. However, detailed petrographic analysis is required to determine the character of the magnetic mineral. As shown in Figure 10, the metasandstone in the Taylors Head formation yields high magnetic susceptibility measurements but based on other data this rock type is low risk in terms of producing acid rock drainage.

\section{CONCLUSIONS}

Rock samples lacking abundant sulphide minerals were purposely collected and analyzed to represent the average lithogeochemistry and ARD potential for units in the metropolitan area of HRM. This study showed that many of these unmineralized rocks have the potential to produce acid. The main acid producers are slate, metasiltstone, and metasandstone of the Beaverbank, Cunard, and Bluestone formations, with the $\mathrm{Cu}$ nard formation having the highest acid-producing potential. The older, dominantly metasandstone-rich Taylors Head formation, as well as the granitoid rocks of the South Mountain Batholith, are non-acid producing. However, the acid-producing potential is greatly increased in contact metamorphosed rocks, especially in the Cunard formation, adjacent to the South Mountain Batholith.

It has been demonstrated that $\mathrm{ARD}$ buffering behaviour is based on the bulk rock chemistry and modal mineralogy of the rock. Hence, knowledge of rock type, alteration characteristics, and depositional environment is important in understanding and predicting the ARD buffering capacity. This study demonstrates that a detailed geological map and petrographic study coupled with lithogeochemical data are needed in order to better ascertain acid rock drainage potential.

Whole rock and sulphur analyses obtained by the portable XRF are a cost-effective way, compared to the acid-base accounting (ABA) test, to estimate the APP/ACA of rocks to provide an early warning of possible ARD problems. Although this approach is not intended as a substitute for the legally mandated ABA test procedure, it could facilitate timely and cost-effective management and mitigation of possible ARD throughout the Goldenville and Halifax groups and in geologically similar areas world-wide.

\section{ACKNOWLEDGEMENTS}

We thank Rebecca Jamieson and John Waldron for their insights into the metamorphic history and stratigraphy of the Bluestone formation and summer students Duncan McLeish, Janice Bell, Alex Kaul, and Kara-Lynn Scallion who contributed to the mapping in HRM. We thank Nova Scotia Department of Natural Resources editor Doug MacDonald, internal reviewer Garth Prime, Atlantic Geology reviewers Drs. Michael Parsons and Donald Fox, and Editor Dr. Sandra Barr for their helpful comments, which led to substantial improvements in the manuscript and their efforts are greatly appreciated. Financial support for this project was provided by the operating budget of the Nova Scotia Department of Natural Resources to the authors. This paper is published with the permission of the Director, Nova Scotia Department of Natural Resources.

\section{REFERENCES}

Bell, F.G., and Bullock, S.E.T. 1996. The problem of acid mine drainage, with an illustrative case history. Environmental and Engineering Geoscience, 2, pp. 369-392.

Betts-Robertson, B.L. 1998. Silicate and sulphide mineral assemblages and metamorphic fabrics from pelites in the contact aureole of the South Mountain Batholith, Halifax area, Nova Scotia. Unpublished B.Sc. thesis, Dalhousie University, Halifax, Nova Scotia, Canada, 101 p.

Blowes, D.W., Ptacek, C.J., Jambor, J.L., and Weisener, C.G. 2005. The geochemistry of acid mine drainage. In Environmental Geochemistry, Treatise on Geochemistry 9. Edited by B.S. Lollar. Elsevier, Oxford, United Kingdom, 631 p.

Boggs, S., Jr., 2001, Principles of Sedimentology and Stratigraphy: Prentice Hall, Upper Saddle River, New Jersey, Third Edition, 726 p.

Campbell, R.N., Lindsay, P., and Clemens, A.H. 2001. Acid generating potential of waste rock and coal ash in New Zea- 
land coal mines. International Journal of Coal Geology, 45, pp. 163-179.

Clarke, D.B., Erdmann, S., Samson, H., and Jamieson, R.A. 2009. Contamination of the South Mountain Batholith by sulphides from the country rock. The Canadian Mineralogist, 47, pp. 1159-1176.

Coastech Research Inc. 1991. Acid rock drainage prediction manual, MEND Project 1.16.1b. URL <http://www.mendnedem.org/reports/files/1.16.1b.pdf>, March, 2011.

Culshaw, N., and Bhatnagar, P. 2001. The interplay of regional structure and emplacement mechanisms at the contact of the South Mountain Batholith, Nova Scotia: floor-down or wall-up? Canadian Journal of Earth Sciences, 38, pp. 1285-1299.

Dickinson, W.R., Beard, L.S., Brakenridge, G.R., Erjavec, J.L., Ferguson, R.C., Inman, K.F., Knepp, R.A., Lindberg, F.A., and Ryberg, P.T. 1983. Provenance of North American Phanerozoic sandstones in relation to tectonic setting. Geological Society of America Bulletin, 94, p. 222-235.

Downing, B.W, and Madeisky, H.E. 1997. Lithogeochemical methods for acid rock drainage studies and prediction. Exploration Mining Geology, 6, pp. 367-379.

Duncan, D. W. and Bruynesteyn, A. 1979: Determination of Acid Production potential of waste materials. American Institute of Mining, Metallurgical and Petroleum Engineers, Paper A79-29, $10 \mathrm{p}$.

Earle J., and Callagnah, T. 1998. Impacts of mine drainage on aquatic life, water uses, and man-made structures. In Chapter 4, Coal mine drainage prediction and pollution prevention in Pennsylvania. The Pennsylvania Department of Environmental Projection, $400 \mathrm{p}$.

Eba Engineering Consultants Ltd. 2004. Heavy metals and acid rock drainage: a selected literature review of remediation and recommendations for applied research. Mining Environment Research Group, Report 2004-2, 22 p. URL http://www.geology.gov.yk.ca/pdf/MPERG_2004_2.pdf, March, 2011.

Faribault, E.R. 1907. Gold fields of Nova Scotia; Summary Report of the Geological Survey Department of Canada for the Calendar Year 1906. Session Paper No. 26, p. 147-152.

Faribault, E.R. 1908. Province of Nova Scotia, Halifax County, City of Halifax sheet, No. 68; Geological Survey Branch of Canada, Department of Mines, Publication No. 1019, scale 1:63 360 .

Feasby, D. G., and Tremblay, G.A. 1995. New technologies to reduce environmental liability from acid generating mine waste. In Proceeding of Conference on Mining and the Environment, Sudbury, Ontario, May 28 to June 1, 1995. Edited by T.P. Hyne and M.V. Blanchette. Centre for Mining and Mineral Exploration Research, Sudbury, pp. 643-647.

Feetham, M., Ryan, R.J., Pe-Piper, G., and O’Beirne-Ryan, A.M. 1997. Lithogeochemical characterization of the Beaverbank unit of the Halifax Formation, Meguma Group, and acid drainage implications. Atlantic Geology, 33, pp. 133-141.

Fitzgerald, R. D., and Goodwin, T. A. 2005. Application of detailed ground magnetic surveys in an acid rock drainage study along Highway 101, Lower Sackville to Mount Uniacke (NTS 11D/13), Nova Scotia. Mineral Resources Branch, Report of Activities 2004. Nova Scotia Department of Natural Resources, Report ME 2005-1, p. 7-13.

Fox,D., Robinson,C., and Zentilli,M. 1997. Pyrrhotite and associated sulphides and their relationship to acid rock drainage in the Halifax Formation. Atlantic Geology, 33, pp. 87-103.

Goodwin, T.A. 2004. Bedrock, glacial, and economic geology of the Halifax Regional Municiality; guidebook for EdGEO field excursion, August 23, 2004. Nova Scotia Department of Natural Resources, Open File Report ME 2004-3, 20 p.

Grande. J.A., Beltrán, R., Sáinz, A., Santos, J.C., de la Torre, M.L., and Borrego, J. 2005. Acid mine drainage and acid rock drainage processes in the environment of Herrerías Mine (Iberian Pyrite Belt, Huelva-spain) and impact on the Andevalo Dam. Environmental Geology, 47, pp. 185-196.

Graves, M.C., and Zentilli, M. 1988. The lithogeochemistry of metal-enriched coticules in the Goldenville-Halifax transition zone of the Meguma Group, Nova Scotia. Geological Survey of Canada, paper 88-1B, pp. 251-261.

Hammarstrom, J.M., Piatak, N.M., Seal, R.R., Briggs, P.H., Meier, A.L., and Muzik, T.L. 2003. Geochemiccal characteristics of TP3 mine wastes at the Elizabeth Copper Mine superfund site, Orange County, Vermont. U.S. Department of the Interior, U.S. Geological Survey, Open File Report 03431, 32 p. URL < http://pubs.usgs.gov/sir/2006/5303/pdf/ Pages_i_thru_50.pdf>, March 2011.

Haysom, S.J., Horne, R.J., and Pe-Piper, G. 1997. The opaque mineralogy of metasedimentary rocks of the Meguma Group, Beaverbank-Rawdon area, Nova Scotia. Atlantic Geology, 33, pp. 105-120.

Herron, M.M. 1988. Geochemical classification of terrigenous sands from core or log data. Journal of Sedimentary Petrology, 58, p. 820-829.

Hicks, R.J. 1996. Low-grade metamorphism in the Meguma Group, southern Nova Scotia. Unpublished M.Sc. thesis, Dalhousie University, Halifax, Nova Scotia, Canada, 352 p.

Hicks, S. A. 2003. Acidic airport drainage, 20 years and $\$ 20$ million worth of experience. Conference Proceedings, Sixth International Conference on Acid Rock Drainage (ICARD), pp. 489-493.

Howells, K., and Fox, D. 1998. Geophysical methods for detecting shallow sulphide mineralization in the Halifax Formation, Nova Scotia: a reconnaissance study. Atlantic Geology, 34, no.3 pp. 211-227.

Ingersoll, R.V., Bullard, T.F., Ford, R.L., Grimm, J.P., Pickle, J.D., and Sares, S.W. 1984. The effect of grain size on detrital modes: A test of the Gazzi-Dickinson point-counting method. Journal of Sedimentary Petrology, 54, p. 103-116.

Jamieson, R.A., Tobey, N.W., and ERTH 3020 2005a. Contact metamorphism of the Halifax Formation on the southeastern margin of the Halifax Pluton, Halifax, Nova Scotia. In Halifax 2005, Geological Association of Canada, Mineralogical Association of Canada, Canadian Society of Petroleum Geology, Canadian Society of Soil Sciences Joint Annual Meeting, Halifax, Nova Scotia, Abstract Volume 30, p. 95. 
Jamieson, R.A., Hart, G.G., Tobey, N.W., and Butler, J.P. 2005 b. Contact metamorphism of the Halifax Formation, Halifax, Nova Scotia. In Mining Matters 2005. Edited by D.R. MacDonald. Nova Scotia Department of Natural Resources, Mineral Resources Branch, Report ME 2005-2, p. 11.

Jamieson, R.A., Waldron, J.W.F., and White, C.E. 2011. Bluestone formation of the Halifax Group: metamorphosed slope and mass-transport deposits, Halifax Peninsula, Nova Scotia. Atlantic Geology, 47, pp. 24-25.

Jennings, S.R., Neuman, D.R., and Blicker, P.S. 2008. Acid mine drainage and effects on fish, health, and ecology: a review. Reclamation Research Group Publication, Bozeman, Montana, 24 p. URL < http://www.pebblescience.org/pdfs/Final_Lit_Review_AMD.pdf>, March, 2011.

Kerekes, J., Freedman, B., Howell, G., and Clifford, P. 1984. Comparison of the characteristics of an acidic eutrophic, and an acidic oligotrophic lake near Halifax, Nova Scotia. Journal of Canadian Water Pollution Research, 19, pp. 1-10.

King, M.S. 1997. Magnetic susceptibility mapping: applications for the Meguma Group, central Nova Scotia. Atlantic Geology, 33, pp. 121-131.

Y.T. John Kwong, Y.T.J, Whitley, G., and Roach, P. 2009. Natural acid rock drainage associated with black shale in the Yukon Territory, Canada. Applied Geochemistry, 24, pp. 221-231.

Lawrence, R.W., and Scheske, M. 1997. A method to calculate neutralization potential of mining wastes. Environmental Geology, 32, pp. 99-106.

Lewis, C.F.M., Taylor, B.B., Stea, R.R., Fader, G.B.J., Horne, R.J., MacNeill, S.G. and Moore, J.G. 1998. Earth science and engineering: urban development in the metropolitan Halifax region. In Urban geology of Canadian cities. Edited by P.F. Karrow and O.L. White. Geological Association of Canada Special Paper 42, p. 409-444.

MacDonald, L.A. 1998. Carbonate in the Oldham gold district, Nova Scotia. Unpublished B.Sc. thesis, Dalhousie University, Halifax, Nova Scotia, Canada, 91 p.

MacDonald, M.A. 2001. Geology of the South Mountain Batholith, southwestern Nova Scotia. Nova Scotia Department of Natural Resources, Minerals and Energy Branch, Open File Report ME 2001-2, 320 p.

MacDonald, M.A., and Horne, R.J. 1987. Geological map of Halifax and Sambro (NTS sheets 11D/12 and 11D/05), Nova Scotia. Nova Scotia Department of Mines and Energy Map 87-6, scale 1:50 000.

Mahoney, K.L. 1996.The contact metamorphic aureole of the South Mountain Batholith, Nova Scotia, Canada. Unpublished M.Sc. thesis, Acadia University, Wolfville, Nova Scotia, Canada, $153 \mathrm{p}$.

Moncur, M.C., Jambor, J.L., Ptacek, C.J., and Blowes, D.W. 2009. Mine drainage from the weathering of sulphide minerals and magnetite. Applied Geochemistry, 24, pp. 23622373.

Moran, P.C., Barr, S.M., White, C.E., and Hamilton, M.A. 2007. Petrology, age, and tectonic setting of the Seal Island Pluton, offshore southwestern Nova Scotia. Canadian Journal of Earth Sciences, 44, pp. 1467-1478.
Morin, K.A., Hutt, N.M., 1, Coulter, T.S., and W M Tekano, W.M. 2003. Case Study of Non-Mining Prediction and Control of Acid Rock Drainage - The Vancouver Island Highway Project. Conference Proceedings, Sixth International Conference on Acid Rock Drainage (ICARD), pp. 495--500.

Nova Scotia Environment Act 1995. Sulphide Bearing Material Disposal Regulations, Nova Scotia Regulation 57/95. Province of Nova Scotia. URL <http://www.gov.ns.ca/just/ regulations/regs/env5795.htm> September 2009.

O’Beirne-Ryan, A.M. 1996. Petrology of coticules from the Meguma Group: a report on selected samples from central Meguma area. Unpublished Nova Scotia Department of Natural Resources Report, Halifax, Nova Scotia, Canada, $49 \mathrm{p}$.

Pasava, J., MacInnis, I., Graves, M., and Zentilli, M., 1995. Black slates - a source of acid drainage at the Halifax International Airport, Nova Scotia, Canada. In Mineral deposits: from their origin to their environmental impacts. Edited by J. Pasava, B., Kribek, and K. Zak. Proceedings of 3rd Biennial Society of Geology Applied to Mineral Deposits Meeting, 28-31 August, Prague, Balkema, Rotterdam, pp. 785-788.

Pelley, D. 2007. Magnetic mineralogy and susceptibility of magnetostratigraphic/ stratigraphic subdivisions of the Goldenville Group, Eastern Shore, Nova Scotia. Unpublished B.Sc. thesis, Dalhousie University, Halifax, Nova Scotia, Canada, $38 \mathrm{p}$.

Peng, B., Wu, F.-C., Xiao, M.-L., Xie, S.R., Lu, H.-Z., and Dai, Y. 2005. Resource function and environment effects of black shales. Bulletin of Mineralogy, Petrology and Geochemistry, 24, pp. 153-158.

Pettijohn, F. J., Potter, P. E., and Siever, R. 1987. Sand and sandstone (2nd ed.). Springer-Verlag, New York, 553 p. http:// dx.doi.org/10.1007/978-1-4612-1066-5

Piispanen, R., and Nykyri, T. 1997. Acidification of groundwater in water-filled gravel pits - a new environmental and geomedical threat. Environmental Geochemistry and Health, 19, pp. 111-126.

Price, W. A. 2005. List of potential information requirements in metal assessment and mitigation work. CANMET Mining and Mineral Sciences Laboratories, Natural Resources Canada. MEND Report 5.10E, 24 p. URL < http://www.responsiblemining.net/pubs/MEND5.10E_Price_Final.pdf> March 2011.

Price, W.A. 2009. Prediction manual for drainage chemistry from sulphidic geologic materials. CANMET Mining and Mineral Sciences Laboratories, Natural Resources Canada. MEND Report 1.20.1, 579 p. URL < http://www.mendnedem.org/reports/details-e.aspx?pub_id=1.20.1> March 2011.

Rajaratnam, T. 2009. Assessment of long-term changes in water quality from Halifax region lakes, Nova Scotia, Canada, using paleolimnological techniques. Unpublished M.Sc. thesis, Queens University, Kingston, Ontario, Canada, 239 p.

Robinson, C. 1996. Pyrrhotite composition and its relationship to acid drainage potential in the Halifax Formation, 
Meguma Group, Nova Scotia. Unpublished B. Sc. Thesis, Dalhousie University, Halifax, Nova Scotia, Canada, 72 p.

Schoeffer, M., and Clawson, P.A. 1996. Identification and treatment of potential acid-producing rocks and water quality monitoring along a transmission line in the Blue Ridge Province, southwest North Carolina. Environmental Engineering Geoscience, 2, pp. 35-88.

Stephenson, M. 2011. Underpass must get done despite bungling. The Chronicle Herald. URL < http://www.thechronicleherald.ca/Opinion/1239484.html> April, 2011.

Talpin,J.2011a. Plans for new terminal altered. MetroNews. URL $<$ http://www.metronews.ca/halifax/local/article/741205-plans-for-new-terminal-altered>, March, 2011.

Talpin,J. 2011b. Bridge stays in terminal plans. MetroNews. URL $<$ http://www.metronews.ca/halifax/local/article/767249-bridge-stays-in-terminal-plans $>$, March 2011.

U.S. Environmental Protection Agency 1994. Acid mine drainage prediction, technical document, EPA530-R-94-036. URL < http://water.epa.gov/polwaste/nps/upload/amd. pdf>, March 2011

van Staal, C. R. 2007. Pre-Carboniferous tectonic evolution and metallogeny of the Canadian Appalachians. In Mineral Resources of Canada: A synthesis of major deposit types, district metallogeny, the evolution of geological provinces, and exploration methods. Edited by W.D. Goodfellow. Geological Association of Canada, Mineral Deposits Division, Special Publication 5, p. 793-818.

Waldron,J.W.F. 1987. Sedimentology of the Goldenville-Halifax transition in the Tancook Island area, South Shore, Nova Scotia. Geological Survey of Canada, Open File 1535, 49 p.

Waldron, J.W.F., White, C.E., Barr, S.M., Simonetti, A., and Heaman, L.M. 2009. Provenance of the Meguma terrane: rifted margin of Early Paleozoic Gondwana. Canadian Journal of Earth Sciences, 46, pp. 1-8.

Weber, P.A., Thomas, J.E., Skinner, W.M., and Smart, R. 2005. A methodology to determine the acid-neutralization capacity of rock samples. The Canadian Mineralogist, 43, pp. 1183-1192.
White, C.E. 2003. Preliminary bedrock geology of the area between Chebogue Point, Yarmouth County, and Cape Sable Island, Shelburne County, southwestern Nova Scotia. In Minerals and Energy Branch, Report of Activities 2002. Edited by D.R. MacDonald. Nova Scotia Department of Natural Resources, Minerals and Energy Branch, Report 2003-1, p. 127-145.

White, C.E. 2010a. Stratigraphy of the Lower Paleozoic Goldenville and Halifax groups in the western part of southern Nova Scotia. Atlantic Geology 46:136-154.

White, C.E. 2010b. Compilation of geochemical and petrographic data from the western and southern parts of the Goldenville and Halifax groups, Nova Scotia. Nova Scotia Department of Natural Resources, Mineral Resources Branch, Digital Open File Report ME2010-001, 18 p.

White, C.E., and Barr, S.M. 2010. Petrochemistry of the Lower Paleozoic Goldenville and Halifax groups, southwestern Nova Scotia, Canada: implications for stratigraphy, provenance, and tectonic setting of Meguma. In From Rodinia to Pangea: The Lithotectonic Record of the Appalachian Region. Geological Society of America Memoir 206, pp. 347-366.

White, C.E., Bell, J.A., McLeish, D.F., MacDonald, M.A., Goodwin, T.A., and MacNeil, J.D. 2008. Geology of the Halifax Regional Municipality, central Nova Scotia. In Mineral Resources Branch, Report of Activities 2007. Edited by D.R. MacDonald. Nova Scotia Department of Natural Resources, Report ME 2008-1:125-139.

Worgan, J. 1987. Acid mine drainage in reactive slates, "The Halifax International Airport Case" Transport Canada perspective. In Proceedings, Acid Mine Drainage Seminar/ Workshop, Halifax, Nova Scotia, March 23-26, 1987. Environment Canada, pp. 127-135.

Zentilli, M., and Fox, D. 1997. Geology and mineralogy of the Meguma group and their importance to environmental problems in Nova Scotia. Atlantic Geology, 33, pp.81 - 85 .

Editorial responsibility Sandra M. Barr 


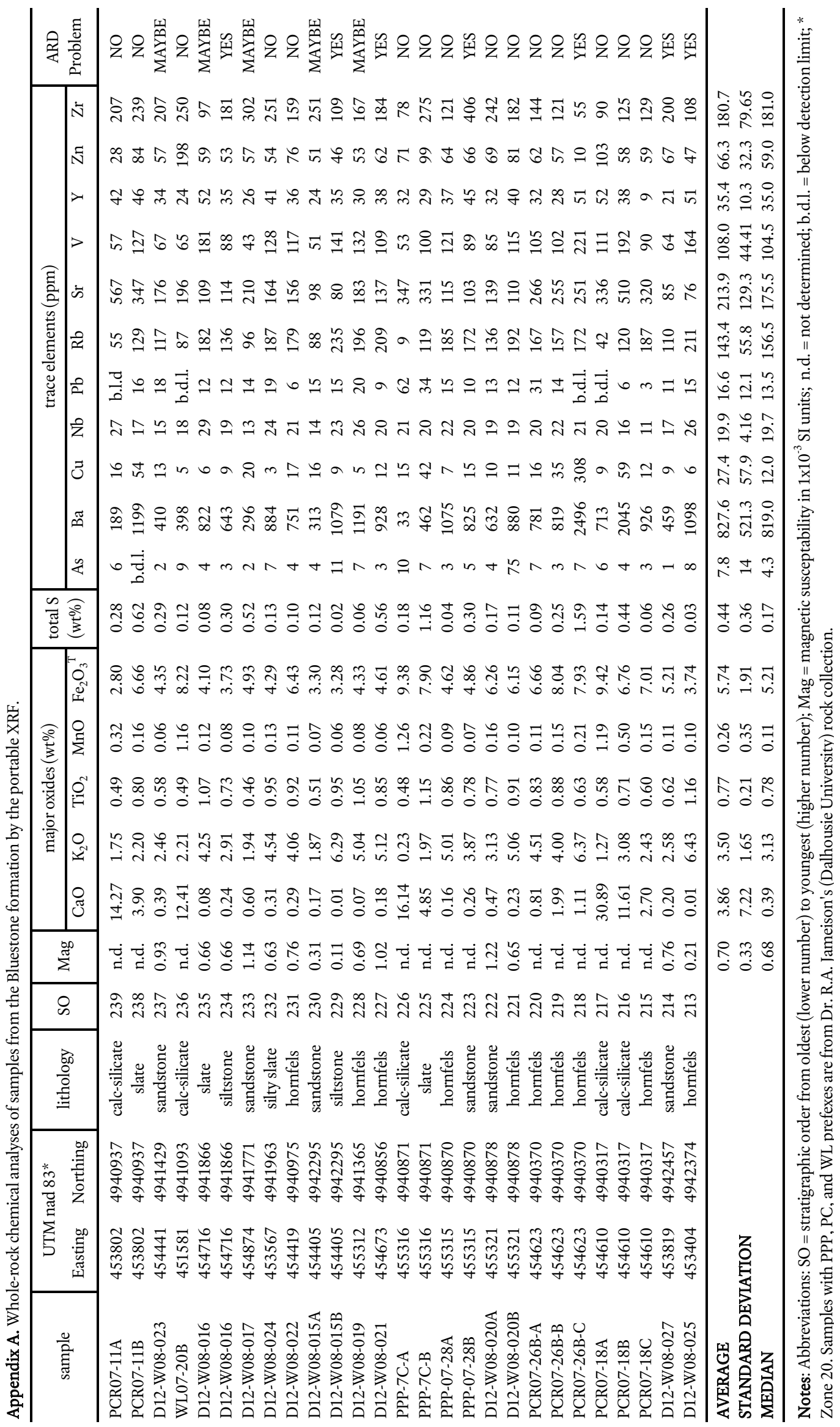




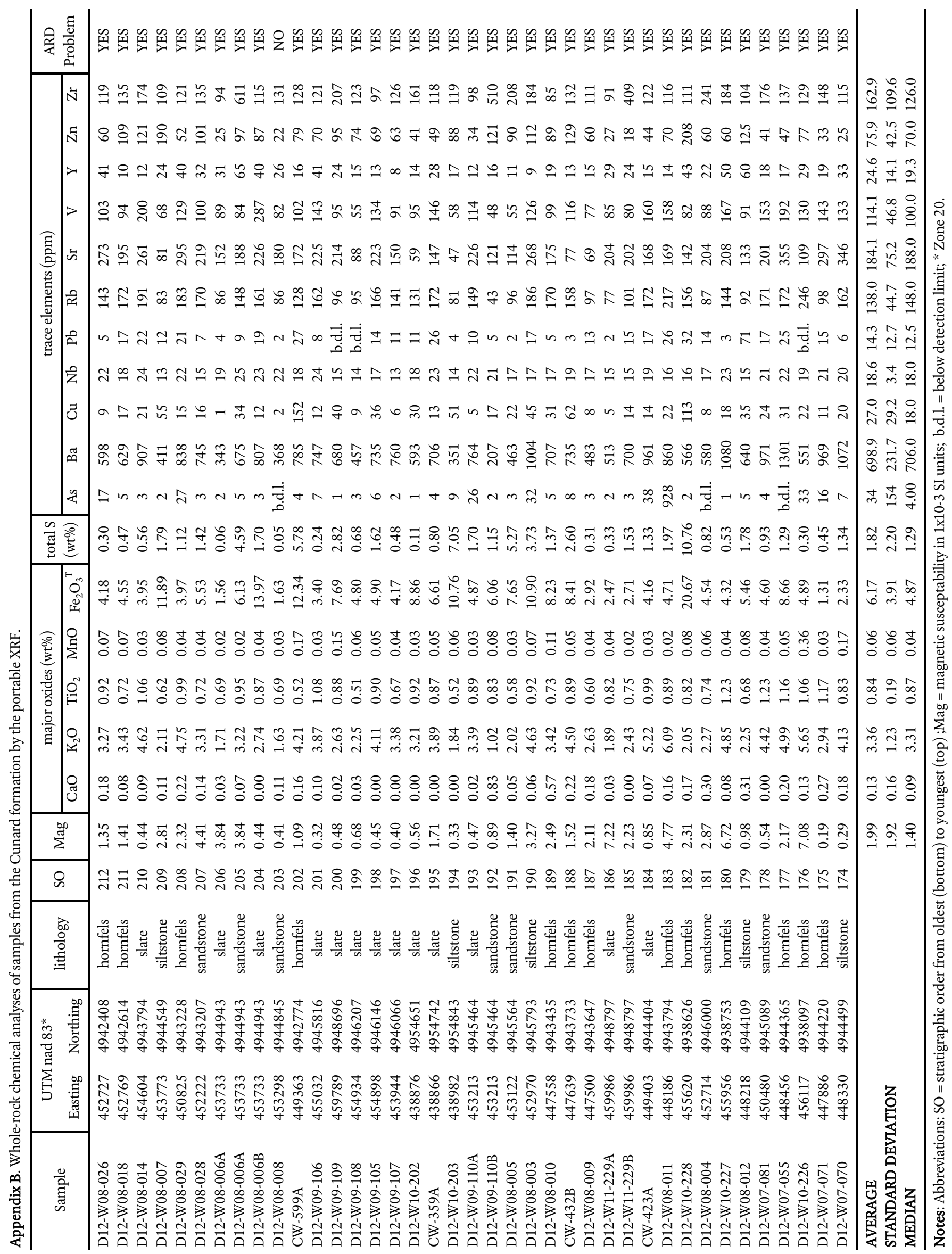




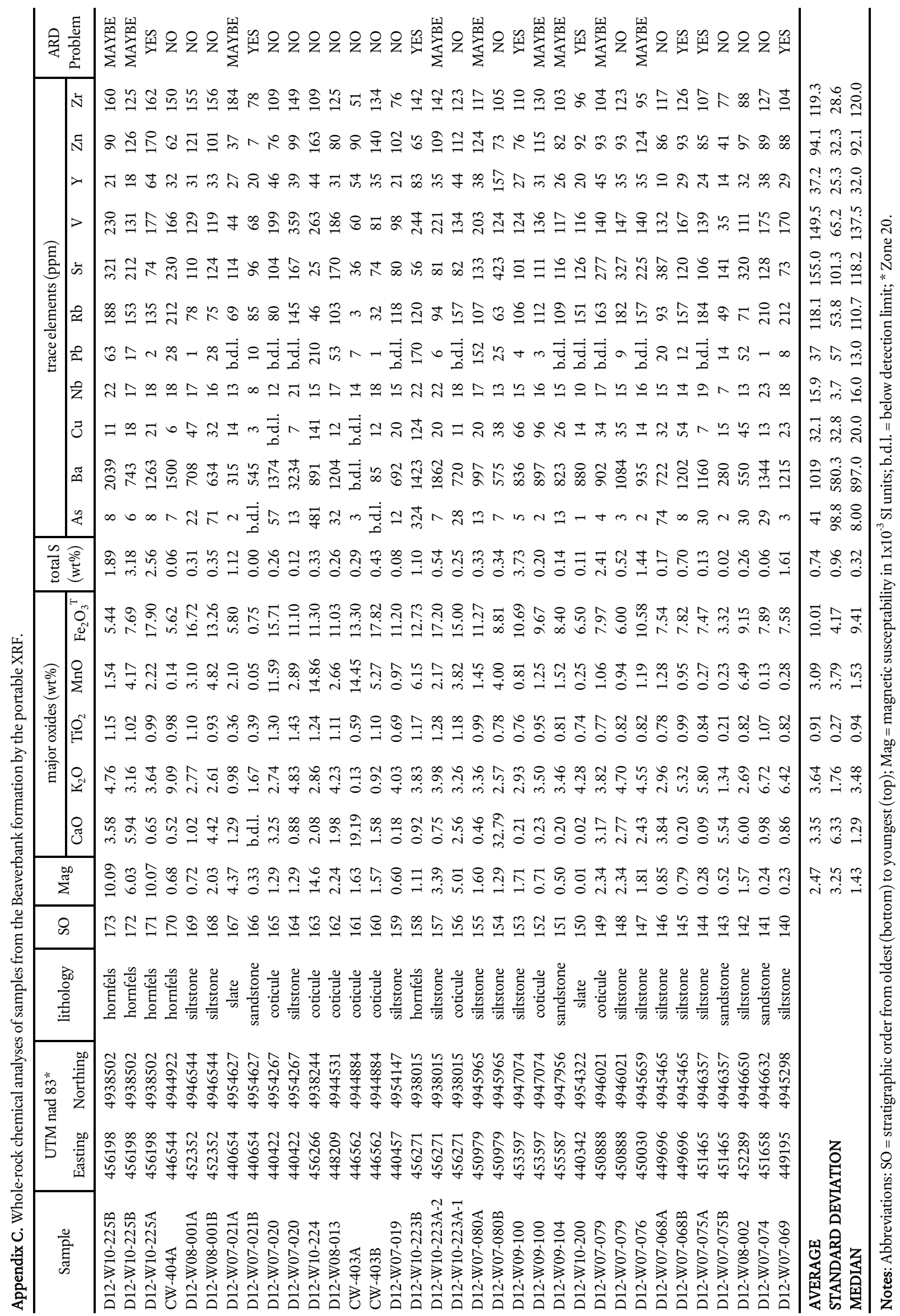




\begin{tabular}{|c|c|}
\hline 轧㔛 & 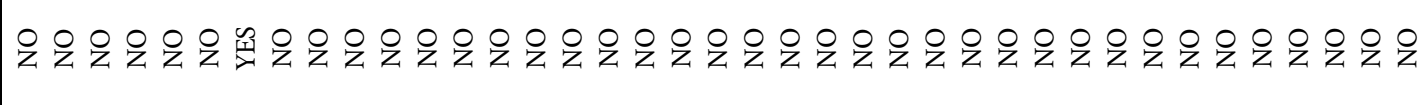 \\
\hline N & 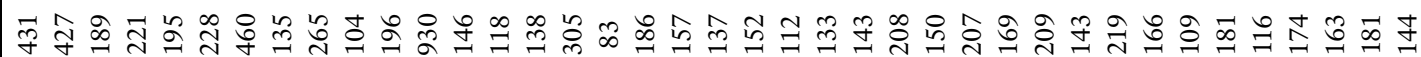 \\
\hline ริ & 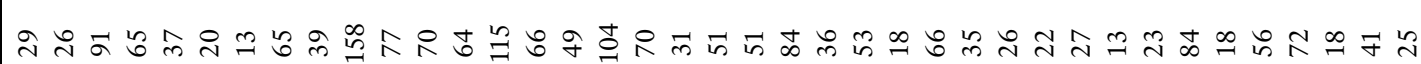 \\
\hline$\succ$ & 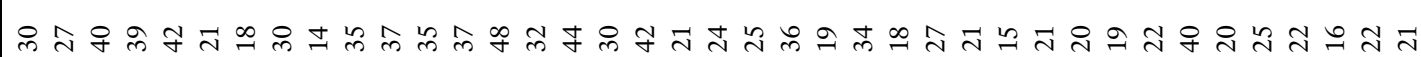 \\
\hline$>$ & in in $\sin ^{2}$ \\
\hline & \\
\hline & 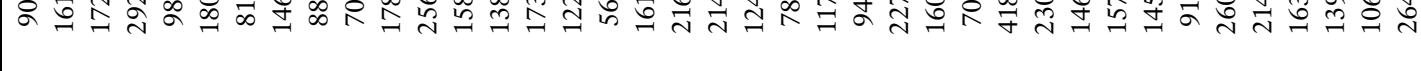 \\
\hline 惡 & ثै \\
\hline 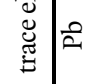 & I \\
\hline $\bar{z}$ & 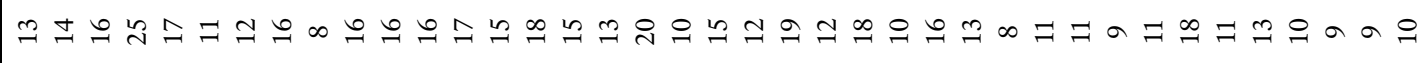 \\
\hline z & 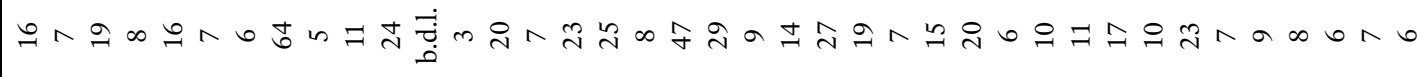 \\
\hline$\tilde{\dddot{m}}$ & 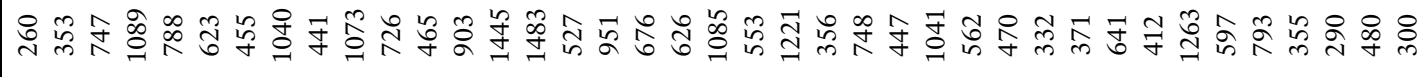 \\
\hline 安 & 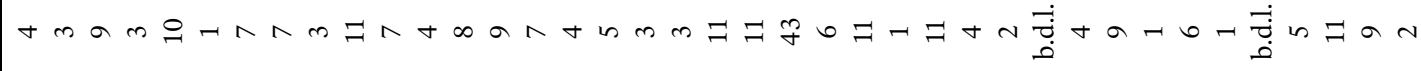 \\
\hline 焉造 & 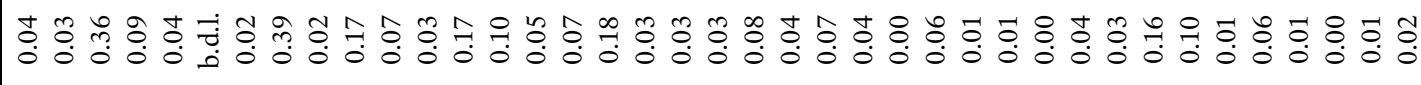 \\
\hline 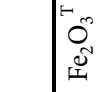 & 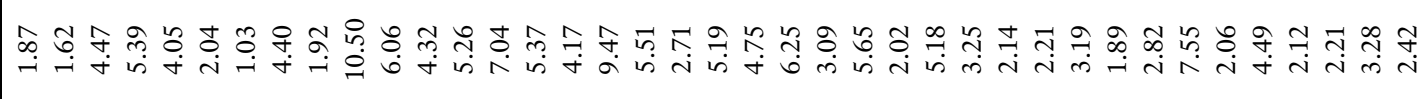 \\
\hline @ & 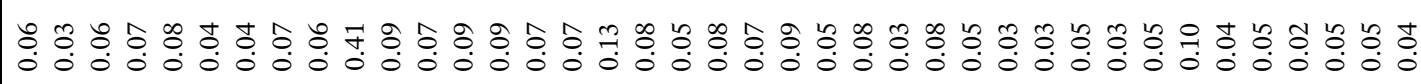 \\
\hline 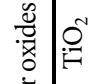 & 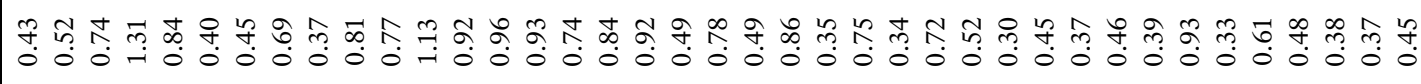 \\
\hline 晃 & 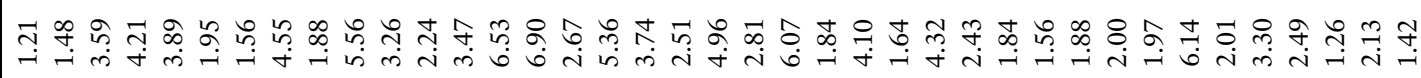 \\
\hline Ö & 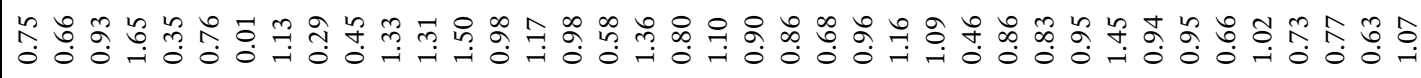 \\
\hline$\stackrel{\infty}{\varlimsup^{\infty}}$ & 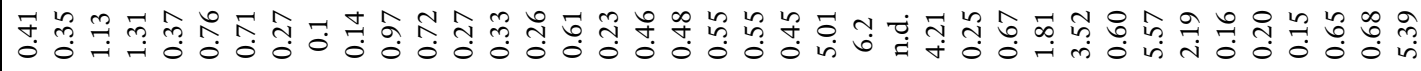 \\
\hline \& & 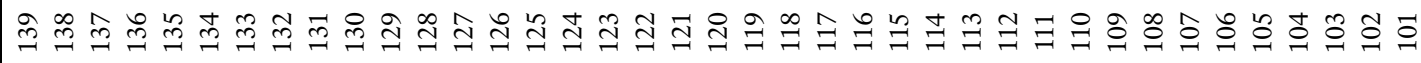 \\
\hline 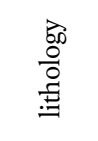 & 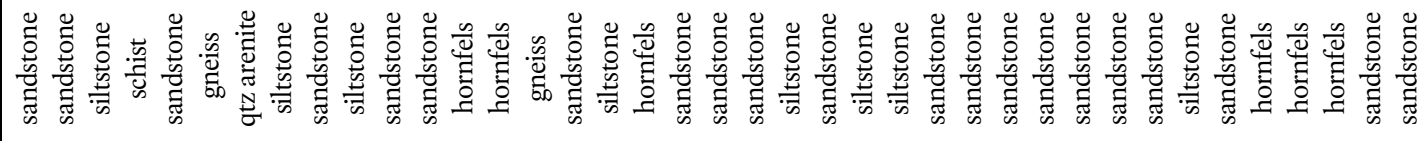 \\
\hline 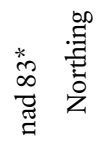 & 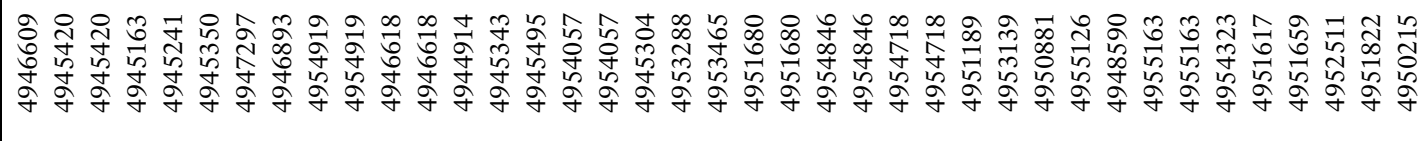 \\
\hline 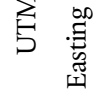 & 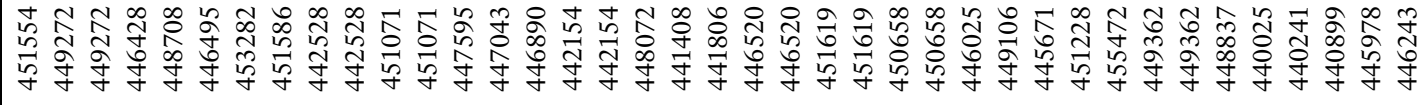 \\
\hline 节 & 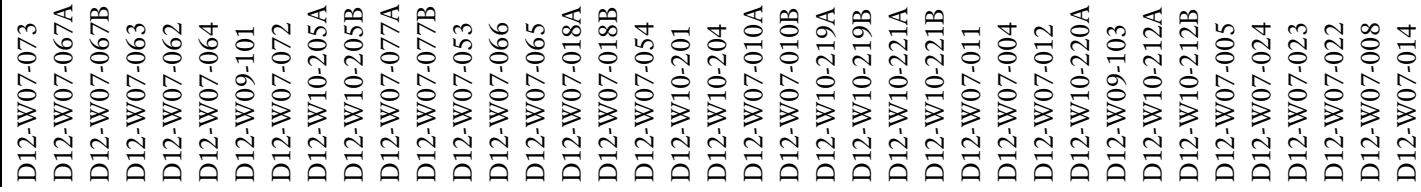 \\
\hline
\end{tabular}




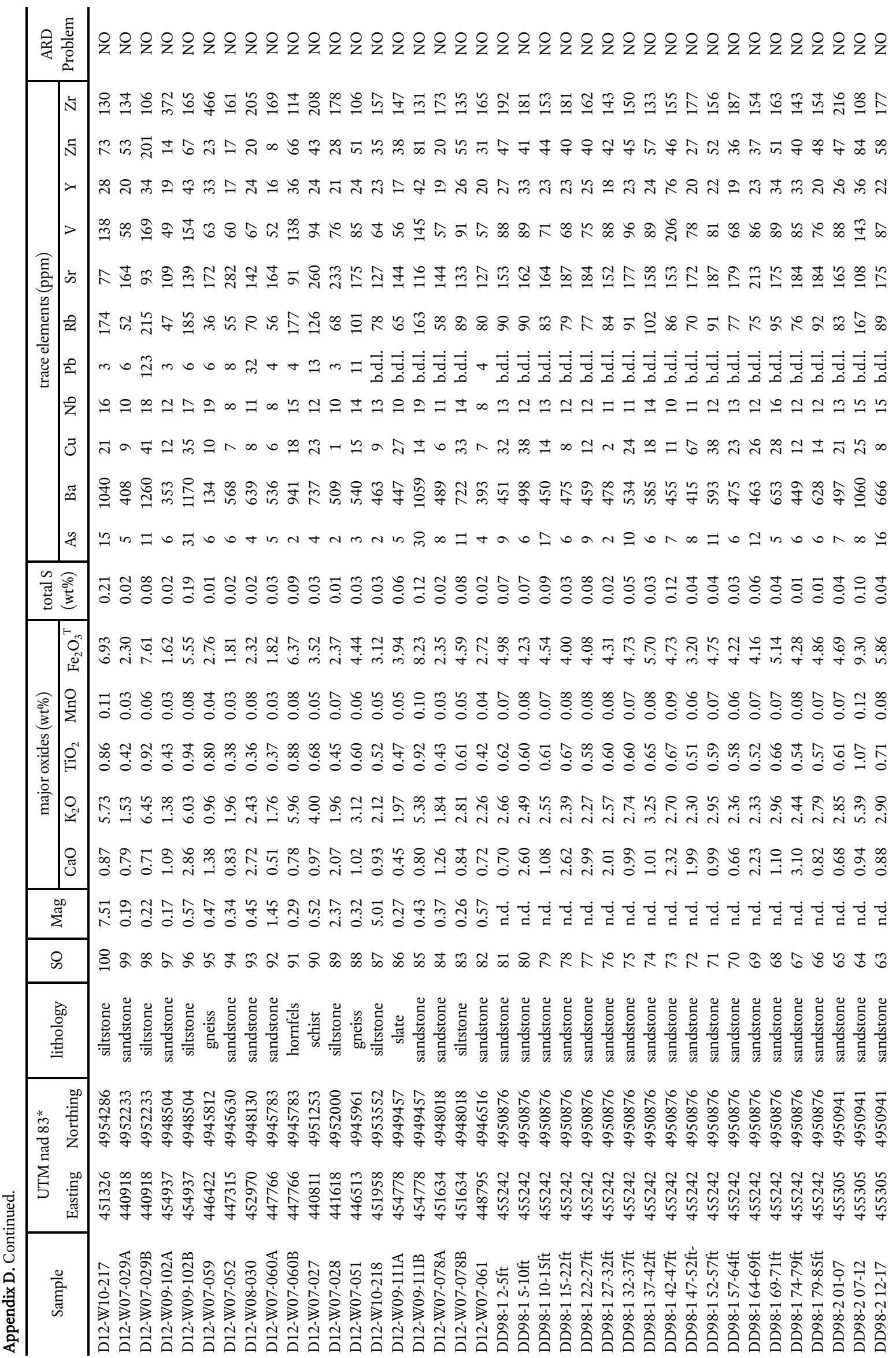




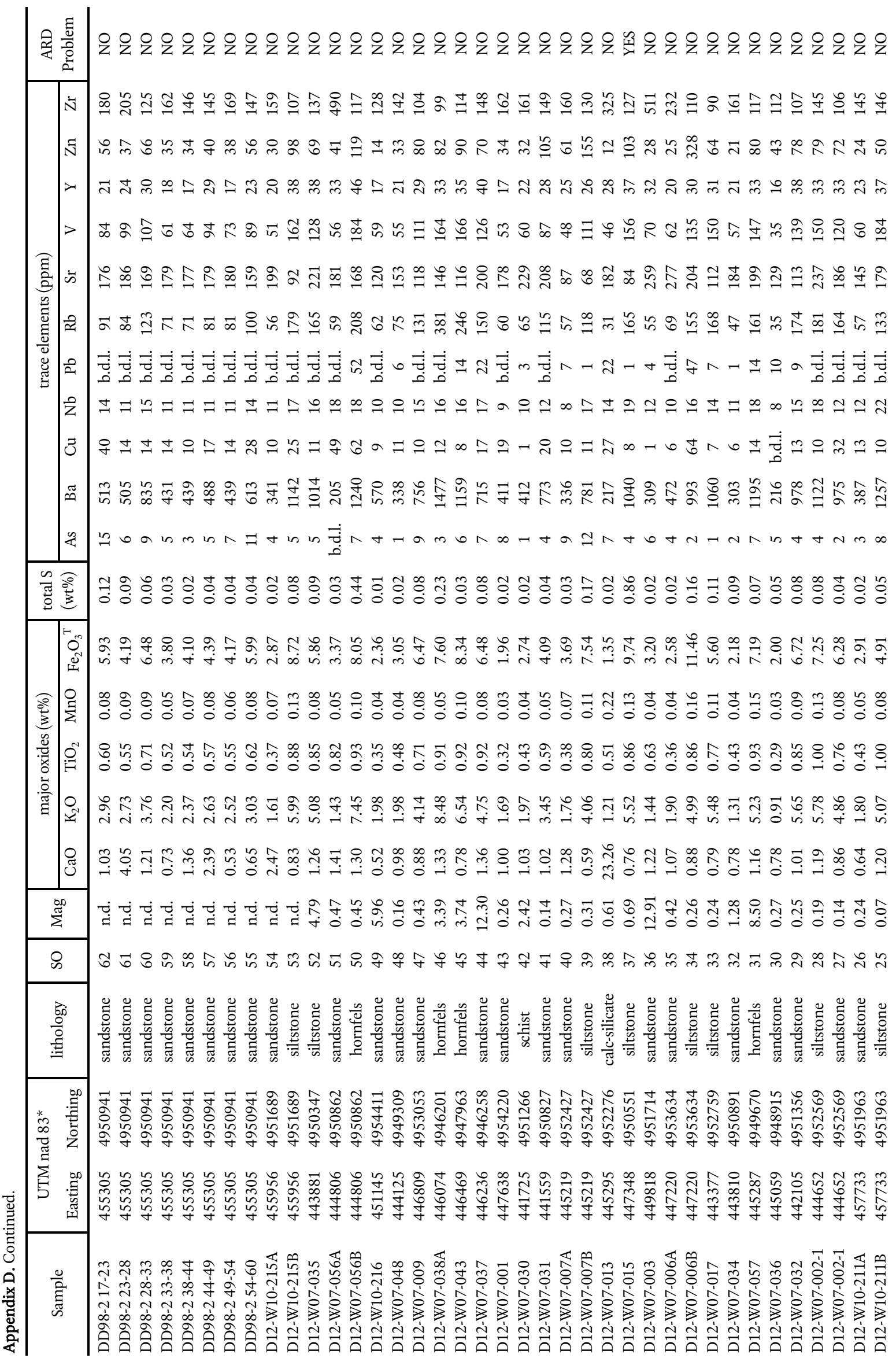




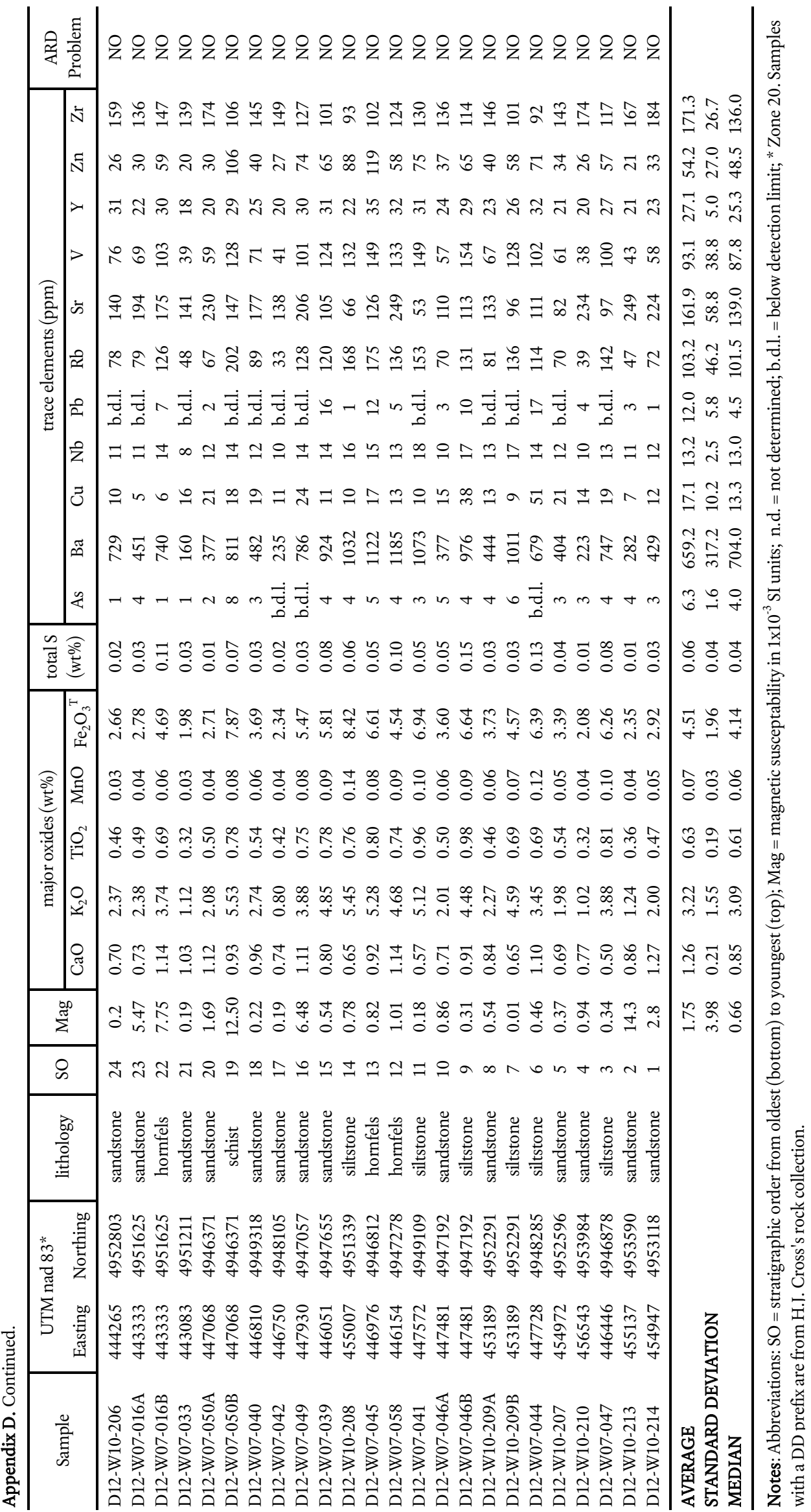




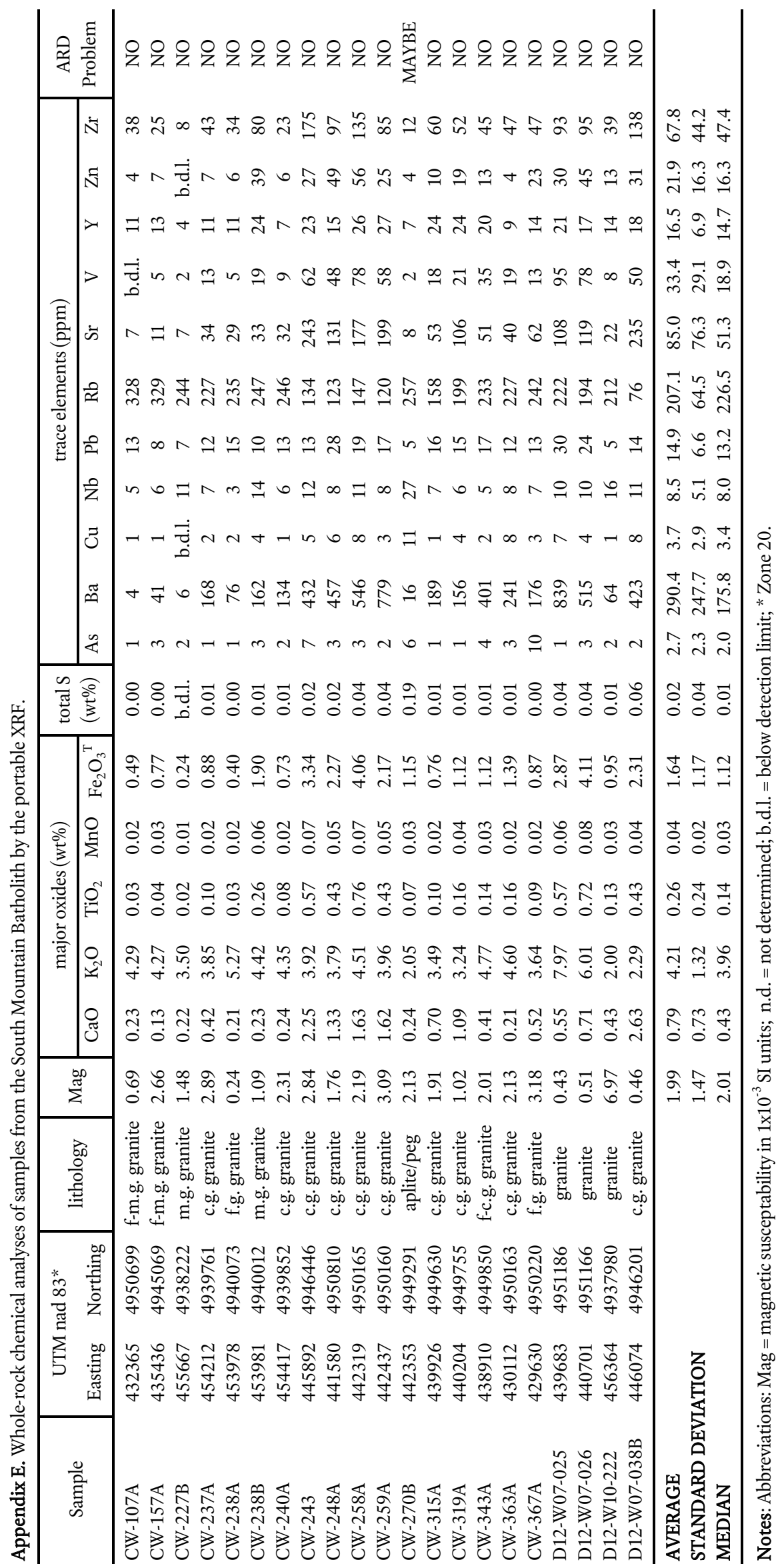

